\title{
Enhanced bacterioplankton production and respiration at intermediate salinities in the Mississippi River plume
}

\author{
Gerardo Chin-Leo*, Ronald Benner \\ University of Texas at Austin, Marine Science Institute, Port Aransas, Texas 78373-1267, USA
}

\begin{abstract}
Bacterial abundance and production (thymidine and leucine incorporation) were measured along a salinity gradient from the Mississippi River $(0 \%)$ to the open waters of the Gulf of Mexico (36\%) during July-August 1990 and February 1991. Bacterial production in surface waters was maximal at intermediate salinities (15 to $30 \%$ ). Nutrient enrichment experiments suggested that bacterial growth near the outflow of the river was $C$ limited whereas bacteria in plume waters of intermediate salinities were $\mathrm{P}$ and $\mathrm{N}$ limited. Rates of plankton community oxygen demand measured during winter were also maximal at intermediate salinities indicating an area of increased heterotrophic activity. The oxygen demand associated with heterotrophic bacterioplankton activity during summer was an important factor leading to hypoxic conditions in bottom waters of the Louisiana continental shelf. In summer, bacterial abundance and production ranged from 0.25 to $3.34 \times 10^{9}$ cells $\mathrm{l}^{-1}$ and from 4 to $90 \mu \mathrm{gC} \mathrm{l}^{-1} \mathrm{~d}^{-1}$, respectively. In winter, the corresponding ranges were 0.36 to $1.09 \times 10^{9}$ cells $\mathrm{I}^{-1}$ and 3 to $20 \mu \mathrm{g} \mathrm{C} \mathrm{l}^{-1} \mathrm{~d}^{-1}$ Depth-integrated bacterial production on the Louisiana shelf decreased from $443 \pm 144 \mathrm{mg} \mathrm{C} \mathrm{m}^{-2} \mathrm{~d}^{-1}$ in summer to $226 \pm 124 \mathrm{mg} \mathrm{C} \mathrm{m}^{-2} \mathrm{~d}^{-1}$ in winter. Using empirically-derived bacterial growth efficiency values of 19 and $29 \%$, we estimated that bacterial production in summer could be supported by 10 to $58 \%$ of phytoplankton production. In winter, the amount of carbon needed to support bacterial production exceeded phytoplankton production suggesting that bacterial growth during this season was heavily dependent on riverine sources of organic matter.
\end{abstract}

\section{INTRODUCTION}

The Mississippi River is one of the largest rivers in the world, ranking sixth in terms of discharge and seventh in terms of sediment load (Milliman \& Meade 1983). The Mississippi drains an extensive area covering $41 \%$ of the contiguous continental USA (Turner \& Rabalais 1991) that includes agricultural lands and major metropolitan centers. The outflow of the river contributes over $70 \%$ of the freshwater input into the Gulf of Mexico (Deegan et al. 1986, calculated from their Table 1) and is a major source of organic (Malcolm \& Durum 1976) and inorganic materials (Fox et al. 1987, Turner \& Rabalais 1991). The discharge of these materials into the gulf has a significant impact on the

\footnotetext{
- Present address: The Evergreen State College, Olympia, Washington 98505, USA
}

productivity and trophic dynamics of the coastal ecosystem. Riverine inorganic nutrients appear to support the high rates of primary production measured on the Louisiana continental shelf (Sklar \& Turner 1981, Lohrenz et al. 1990), and the subsequent decomposition of this freshly produced organic matter in addition to the respiration of organic matter introduced by the river result in hypoxic conditions during summer in bottom waters near the Mississippi River delta (Turner \& Allen 1982a, b, Rabalais et al. 1991).

An understanding of the dynamics of materials introduced by the Mississippi into the Gulf of Mexico is necessary to determine the impact of the river on the coastal ecosystem. Heterotrophic bacteria are the major consumers of dissolved organic matter (DOM) (Wright 1984) and dissolved oxygen (Williams 1984) in most aquatic ecosystems, and can also play an important role in trophic dynamics (Azam et al. 
1983, Ducklow 1983, Cole et al. 1988). Therefore, estimates of bacterial activity are important in understanding the impact of riverine inputs on coastal processes. Few studies have examined the role of bacteria in river plumes. In general, bacterial rates of production have been found to be enhanced at the boundaries between river water and ocean water (Albright 1983, Ducklow \& Kirchman 1983, Kirchman et al. 1989). These elevated rates of bacterial production appear to result from bacterial utilization of riverine organic matter in addition to organic matter produced by phytoplankton in situ (Albright 1983, Ducklow \& Kirchman 1983, Kirchman et al. 1989). A significant contribution of riverine DOM to bacterial growth may explain the poor correlation between bacterial and phytoplankton primary production found in river plumes (Albright 1983, Ducklow \& Kirchman 1983).

In this study, bacterial production and abundance were measured during summer and winter across the salinity gradient of the Mississippi River plume, in oligotrophic waters of the Gulf of Mexico and at sites within the river. Estimates of depth-integrated bacterial production indicate that bacteria are abundant and active components of the plankton that contribute substantially to the cycling of organic matter and to the consumption of dissolved oxygen. During both seasons, bacterial production in surface waters was enhanced at intermediate salinities (15 to $30 \%$ ) coinciding with the area of maximal phytoplankton biomass which suggests that phytoplankton growth contributed significantly to bacterial production. However, in winter, the amount of carbon required to sustain bacterial production was much greater than that produced by phytoplankton suggesting that riverine organic matter contributed substantially to bacterial production during this season.

\section{MATERIALS AND METHODS}

Study site and sampling procedures. An area of the northern Gulf of Mexico (Fig. 1) near the discharge of the Mississippi River was surveyed during 2 cruises of the NOAA vessel 'Malcolm Baldrige' from 18 July to 8 August 1990 and from 19 to 28 February 1991. Nearly $70 \%$ of the river's discharge flows out of the Mississippi River delta. The remaining $30 \%$ enters the Gulf of Mexico through the Atchafalaya River, a large distributary of the Mississippi which flows into the Gulf west of the main delta. This study focused on bacterial activity along a salinity gradient ( 0 to $36 \%$ ) associated with the main delta of the Mississippi. Samples were obtained near the outflows of the 4 major channels on the delta: the Southwest Pass, the South Pass, the Pass à Loutre and the Main Pass, and at stations to the west and to the south of the delta on the Louisiana shelf. The salinity gradient associated with Southwest Pass, which discharges most (ca $50 \%$ ) of the water from the delta, was sampled in more detail. A small boat was used for sampling at the mouth of the Southwest Pass. From 4 to 8 samples were obtained between the salinities of 0 to $17 \%$. Areas to the west and to the south of the delta were sampled from the 'NV Baldrige' to collect water of higher salinities ( 8 to $36 \%$ ) as river water mixed with seawater. The plume of the Mississippi River was defined to be waters of salinities $>0$ and $<30 \%$. Measurements of bacterial activity in the plume were compared to those measured within the river $(0 \%)$, and in ocean water $(36 \%)$ of the continental slope and the open gulf. Surface samples were collected with clean plastic buckets or polycarbonate bottles. Subsurface samples were obtained with Niskin bottles secured to a Kevlar line or mounted on a rosette with a Neil Brown Mk III CTD. During field sampling salinity was determined by refractive

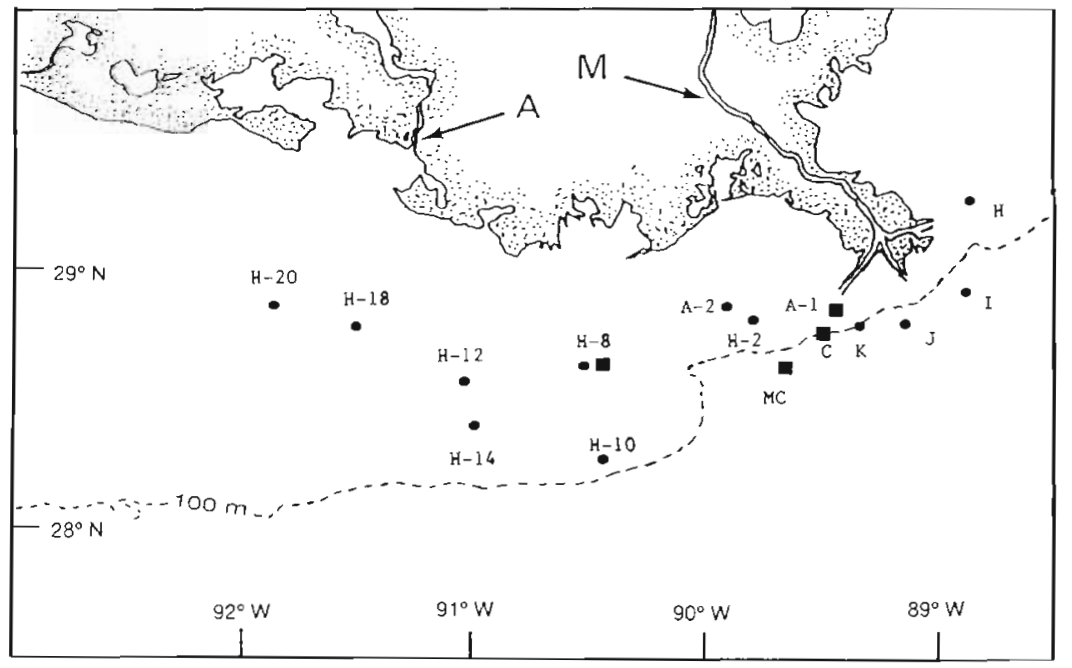

Fig. 1. Area surveyed on the Louisiana shelf showing the location of the Mississippi River $(M)$, the Atchafalaya River (A), and the location of stations where estimates of depthintegrated bacterial production were obtained. (•) Stations sampled during July and August $1990_{i}$ ( ) stations sampled in February 1991 Coordinates for these stations are given in Table 1 
index (Reichert refractometer) or conductivity (Neil Brown or Seacat CTD). Salinity from some samples was also determined with a Guildline 8400 Autosal salinometer. Values obtained with the refractometer were within $1 \%$ from those determined by conductivity for the same water samples.

Bacterial abundance and production. Bacterial abundance was measured using epifluorescence microscopy of DAPI stained samples (Porter \& Feig 1980). Samples were analyzed in duplicate, and bacteria in at least 10 fields were counted for each microscope slide (Kirchman et al. 1982). Bacterial production was estimated from rates of DNA and protein syntheses as measured by a dual-label method using $\left[{ }^{3} \mathrm{H}\right]$ Thymidine (TdR) and $\left[{ }^{14} \mathrm{C}\right]$ Leucine (Leu) (Chin-Leo \& Kirchman 1988). Triplicate water samples (10 ml) were incubated with $10 \mathrm{nM}$ (final concentration) $\left[{ }^{3} \mathrm{H}\right] \mathrm{TdR}$ (specific activity of $84.1 \mathrm{Ci} \mathrm{mmol}^{-1}$ ), and $20 \mathrm{nM}$ (final concentration) $\left[{ }^{14} \mathrm{C}\right]$ Leu (specific activity of $328.5 \mathrm{mCi}$ $\mathrm{mmol}^{-1}$ ) for $30 \mathrm{~min}$. Rates of uptake of both compounds were linear for at least $60 \mathrm{~min}$. Saturating concentrations of radiolabeled substrates $(5 \mathrm{nM}$ TdR and $10 \mathrm{nM}$ Leu) were determined experimentally by measuring incorporation rates at various concentrations of substrate. All radioactive substrates were from New England Nuclear (Boston, MA, USA). The nucleic acid and protein fractions were separated in all samples as described by Chin-Leo \& Benner (1991) to test for the possible non-specific incorporation of TdR into protein. Replicate measurements of bacterial abundance and bacterial production (TdR and Leu incorporation) differed by $<10$ and $<5 \%$, respectively. Abiotic absorption of the labeled substrates was estimated by measuring the incorporation of radiolabeled substrates in samples previously fixed with formaldehyde $10 \%$ final concentration). All samples were corrected for abiotic incorporation by subtracting the radioactivity in the formalin-killed controls.

Bacterial abundance and production were measured in surface waters and at several depths on the shelf. Depending on the depth of the water column, from 3 to 8 samples were collected to sample surface waters, the pycnocline and bottom waters. In addition, subsurface peaks of particles detected by a transmissometer were sampled. Surface and bottom waters were kept near $\left( \pm 2^{\circ} \mathrm{C}\right)$ in situ temperatures in 2 different incubators. In shelf waters $(<100 \mathrm{~m})$, rates of $\mathrm{TdR}$ and Leu incorporation were integrated over the depth of the water column to estimate bacterial production on an areal basis. Depth-integrated incorporation rates were calculated by adding the areas of rectangles with base equal to the difference in depth between consecutive samples and length equal to the incorporation rate of the deepest sample of the pair. Most surface samples were taken slightly $(0.1$ to $1 \mathrm{~m})$ below the surface to avoid contamination by the surface microlayer. In the rectangle that included the surface waters, we assumed that the incorporation rate was constant from the surface $(0 \mathrm{~m})$ to the first sample depth $(0.1$ to $1 \mathrm{~m}$ ). The step-wise rectangular integration method does not require interpolating between points and yields conservative estimates when incorporation rates decrease with depth. In this study, incorporation rates always decreased with depth. Rates of TdR incorporation were converted to rates of $C$ production using an empirically-determined factor obtained by comparing total TdR incorporation with increases of bacterial numbers (Kirchman \& Hoch 1988) and using a cell to $\mathrm{C}$ conversion value of $20 \mathrm{fg} \mathrm{C}$ cell- ${ }^{-1}$ (Lee \& Furhman 1987). Experiments to determine empirical conversion factors were performed during summer using Mississippi River plume water. Estimates of bacterial C production were determined from rates of Leu incorporation using the conversion factor of $3.1 \mathrm{~kg} C$ produced $\mathrm{mol}^{-1}$ of Leu incorporated (assumes an internal isotope dilution of 2) derived by Simon \& Azam (1989).

Nutrient enrichment and plume water addition experiments. The possible limitation of bacterial growth by the availability of $\mathrm{C}, \mathrm{N}$ or $\mathrm{P}$ along the salinity gradient was investigated by measuring changes in bacterial production following additions of glucose $(100 \mu \mathrm{M}), \mathrm{NH}_{4} \mathrm{Cl}(50 \mu \mathrm{M})$, or $\mathrm{KH}_{2} \mathrm{PO}_{4}(10 \mu \mathrm{M})$ (final concentrations). The concentrations of added compounds were chosen to at least triple the expected ambient concentrations. Each of 3 replicate samples (1 l) was amended with one of these compounds. A fourth replicate sample received an addition of both $\mathrm{NH}_{4} \mathrm{Cl}(50 \mu \mathrm{M})$ and $\mathrm{KH}_{2} \mathrm{PO}_{4}(10 \mu \mathrm{M})$ to test for possible co-limitation of growth by $\mathrm{N}$ and $\mathrm{P}$. A fifth replicate sample was left unamended and served as a control. Samples were kept in the dark to minimize the uptake of $\mathrm{NH}_{4}{ }^{+}$and $\mathrm{PO}_{4}{ }^{-3}$ by phytoplankton, and were incubated at the in situ temperature for 35 to $45 \mathrm{~h}$. Subsamples were obtained from each treatment approximately every $8 \mathrm{~h}$ and analyzed for bacterial abundance and production. These experiments were repeated during both cruises with water of various salinities.

During July 1990, bacterial assemblages from open gulf waters $(36 \%)$ were mixed with filter-sterilized water of low salinity water $(16 \%)$ collected near the discharge of the Mississippi River to mimic the mixing of river and gulf water and to test whether materials introduce by the river could enhance bacterial growth. Three parts of water $(1.5 \mathrm{l})$ of a salinity of $36 \%$ were mixed with one part water $(0.5$ l) of a salinity of $16 \%$ which had been filtered through a $0.2 \mu \mathrm{m}$ pore size filter. Treatments were done in duplicate. Results were compared to samples in which $1.5 \mathrm{l}$ of $36 \%$ water was mixed with $0.5 \mathrm{l}$ of $36 \%$ water 
filtered through a $0.2 \mu \mathrm{m}$ filter. Water was gently filtered through Nuclepore cartridge filters using a peristaltic pump. Samples were kept in the dark at a constant temperature for $45 \mathrm{~h}$. Subsamples were obtained approximately every $8 \mathrm{~h}$ and analyzed for bacterial abundance and production. Dissolved organic carbon (DOC) concentrations in the treatments were measured with a Shimadzu TOC 5000 analyzer using a platinum catalyst and high-temperature oxidation $\left(680^{\circ} \mathrm{C}\right)$.

Bacterial growth efficiency. The growth of natural assemblages of bacteria was examined under controlled conditions to estimate bacterial growth efficiencies on DOM. These experiments were performed in summer and winter with water of various salinities. In summer, water samples were gently pumped through $1 \mu \mathrm{m}$ pore-size Nuclepore cartridge filters to remove most phytoplankton and grazers. In winter, water samples were filtered through $3 \mu \mathrm{m}$ pore-size cartridge filters and diluted 1:5 with $0.2 \mu \mathrm{m}$ filtered water. Both methods, size fractionation and dilution, reduce the concentration of particulate matter and reduce the impact of grazers on bacteria. Treated water was placed in duplicate $9 \mathrm{l}$ glass bottles and was kept in an incubator at the in situ temperature in the dark. Bottles were sealed with silicon stoppers to prevent exchange of gases with the atmosphere. Each bottle was connected by Teflon tubing to a 2 l bottle filled with the same water. This smaller bottle served as a reservoir to replenish the water removed during sampling and thus avoid aeration in the larger bottles. Bottles were incubated for 2 to $5 \mathrm{~d}$ and sampled for bacterial production at approximately $24 \mathrm{~h}$ intervals. Samples for dissolved oxygen (DO) were collected at the beginning, middle and end of the experiment. Bacterial growth efficiency was estimated by comparing gross (production plus respiration) to net production. Net production was estimated from the rates of $\mathrm{TdR}$ and Leu incorporation integrated over the duration of the incubation. TdR and Leu incorporation rates were converted to $\mathrm{C}$ by using the conversion factors described above. Gross production was estimated by adding net production to the amount of $\mathrm{C}$ respired. Respired $C$ was estimated from DO utilization assuming a respiratory quotient (RQ) of 1. DO was measured using the Winkler method (see below).

Plankton community respiration. During February 1991, rates of oxygen utilization by the plankton community were measured at various locations along the salinity gradient. These rates were compared to rates of bacterial production ( $\mathrm{TdR}$ and Leu incorporation) measured concurrently. DO concentration was determined using the Winkler method as modified by Carrit \& Carpenter (1966). Rates of oxygen utilization were calculated from changes in DO concentration over a
24 h period. DO was never depleted over the course of these experiments. We assumed a linear rate of DO utilization. Four replicate samples were collected in $250 \mathrm{ml}$ BOD (biological oxygen demand) bottles. Two bottles were fixed immediately with $1 \mathrm{ml}$ of $\mathrm{MnCl}_{2}$ (3 M) and $1 \mathrm{ml}$ of $\mathrm{NaOH}-\mathrm{NaI}(8 \mathrm{~N}-4 \mathrm{M})$ solution. After mixing and allowing the precipitate to settle, $1 \mathrm{ml}$ of $\mathrm{H}_{2} \mathrm{SO}_{4}(10 \mathrm{~N})$ was added and the sample was analyzed for DO. The remaining 2 bottles were incubated in the dark at the in situ temperature for $24 \mathrm{~h}$. Following the incubation, samples were fixed as described above and analyzed. Fixed samples were titrated with an automated titration system controlled by a HP-85 computer (Friederich et al. 1984). Titrant $\left(\mathrm{Na}_{2} \mathrm{~S}_{2} \mathrm{O}_{3}\right)$ was added by a computer-controlled automated buret, and the endpoint was detected colorimetrically using a light source and a photodiode sensor. Replicate measurements differed by $<5 \%$. At selected stations additional replicates were collected in triplicate and analyzed independently with a manually operated Winkler system with an optical end-point determination. The difference between DO values measured with these systems was $<10 \%$. Removal of DO by abiotic factors was estimated by measuring the change in DO after $24 \mathrm{~h}$ in replicate samples filtered through a $0.2 \mu \mathrm{m}$ Nuclepore filter. Estimates of oxygen consumption in filter-sterilized water were reproducible and were $<10 \%$ of the rates in unfiltered water.
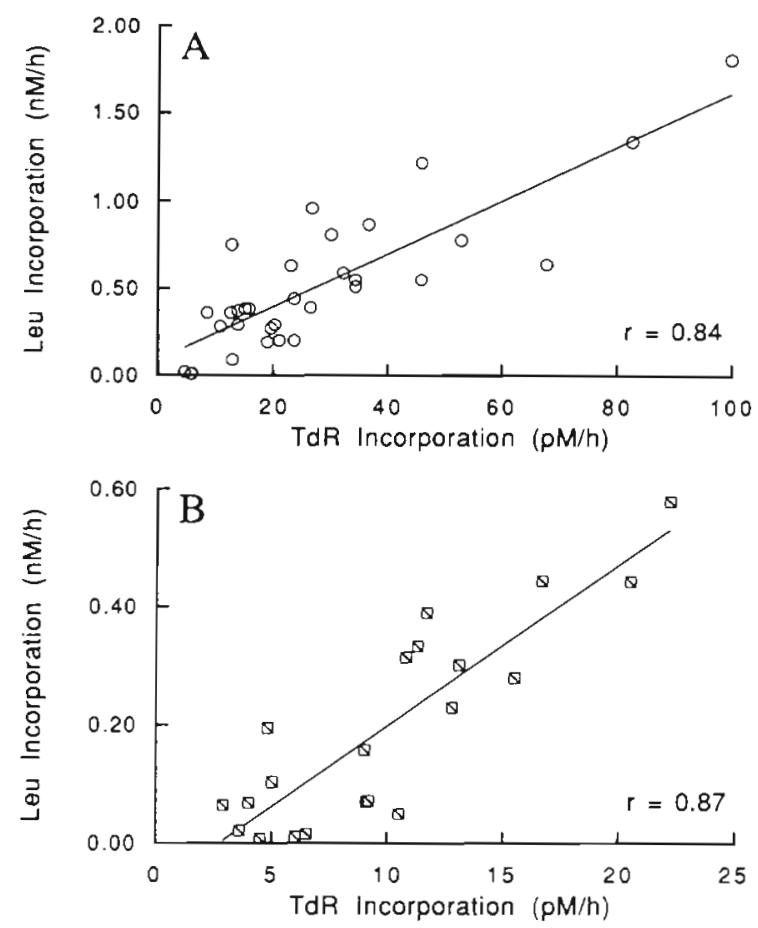

Fig. 2. Scatter plots of rates of TdR incorporation versus rates of Leu incorporation during (A) July-August 1990 and (B) February 1991. Lines-of-best-fit are plotted through the points 


\section{RESULTS}

\section{Distribution of bacterial abundance and production along a salinity gradient}

During summer, surface-water temperatures along the salinity gradient ranged from $28^{\circ} \mathrm{C}$ in river water to $30^{\circ} \mathrm{C}$ in gulf water. During winter, over the same salinity range, the surface water temperature ranged from 8 to $20^{\circ} \mathrm{C}$. TdR and Leu incorporation were measured simultaneously in all samples to obtain independent estimates of bacterial growth. Rates of $\mathrm{TdR}$ and Leu incorporation measured in surface waters during field surveys were significantly correlated during summer $(r=0.84 ; n=30, p=0.0001)$ (Fig. 2A) and winter $(\mathrm{r}=0.87 ; \mathrm{n}=21, \mathrm{p}=0.0001)$ (Fig. 2B).

Bacterial abundance and rates of TdR and Leu incorporation in surface waters were plotted versus salinity to examine changes in bacterial activity as river water mixed with gulf water (Fig. 3). During summer, bacterial abundance ranged from 0.20 to $3.34 \times 10^{9}$ cells $^{-1}$. Cell abundances were maximal at $0,2,16$ and $17 \%$ near the mouth of Southwest Pass and were minimal in $36 \%$ water (Fig. $3 \mathrm{~A}$ ). TdR and Leu incorporation rates also varied over the salinity gradient. Rates of TdR incorporation ranged from 5 to $100 \mathrm{pM} \mathrm{h}^{-1}$ and rates of Leu incorporation ranged from 0.01 to $1.80 \mathrm{nM} \mathrm{h}^{-1}$ Maximal rates of TdR and Leu incorporation occurred at intermediate salinities (16 to $30 \%$ ) while lower values were measured in fresher waters and in open gulf waters (Figs. 3B, C).

Overall, bacterial abundances and production were lower in winter than summer. Bacterial abundance

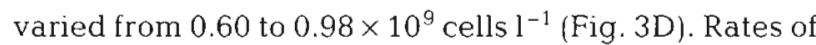
$\mathrm{TdR}$ and Leu incorporation varied from 3 to $22 \mathrm{pM} \mathrm{h}^{-1}$ and from 0.04 to $0.69 \mathrm{nM} \mathrm{h}^{-1}$, respectively. As in summer, rates of $\mathrm{TdR}$ and Leu incorporation paralleled each other with highest rates of incorporation occurring at intermediate salinities (Figs. 3E, F).
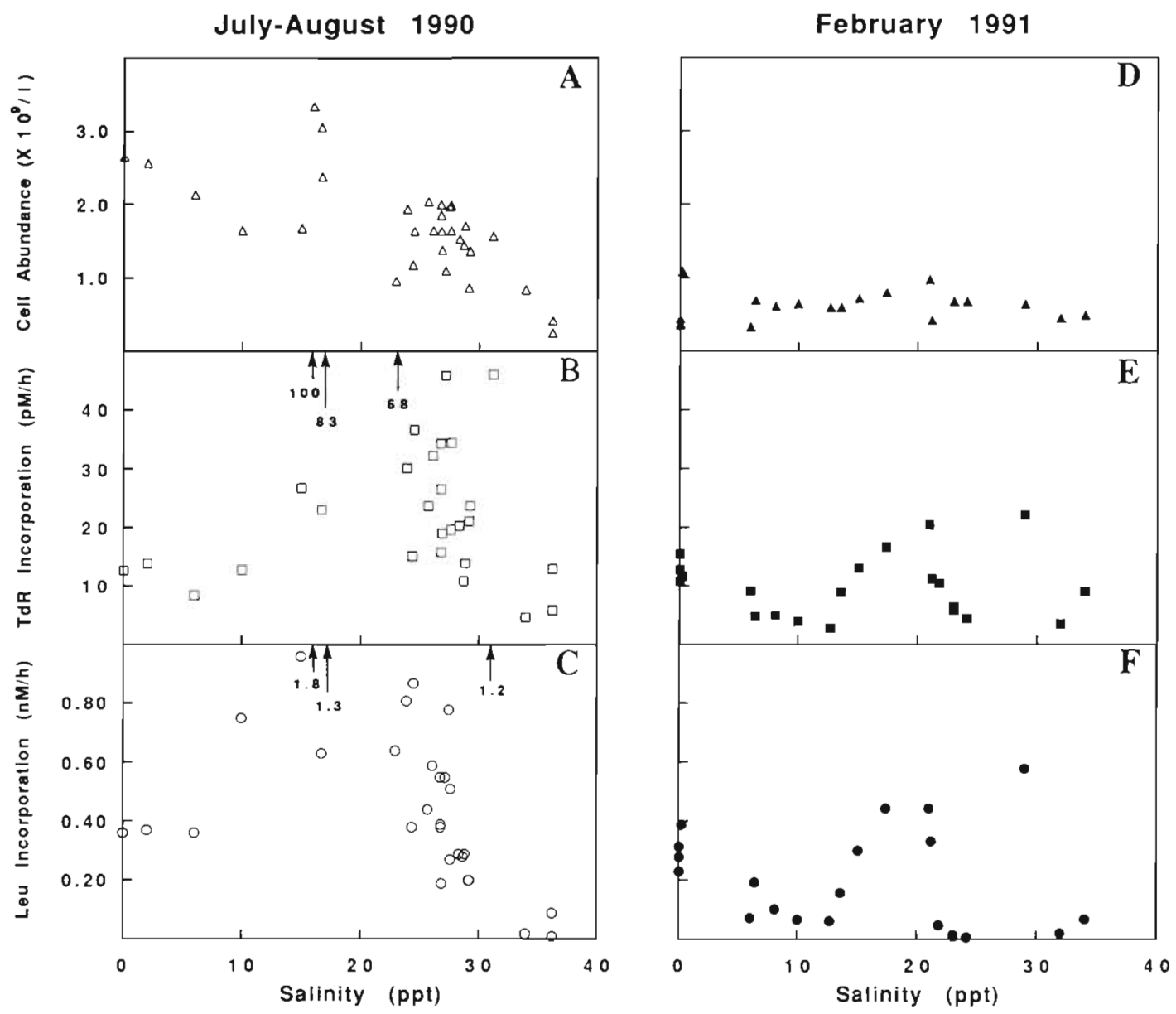

Fig. 3. Scatter plots of surface water distributions during July-August 1990 of (A) cell abundance, (B) rates of TdR incorporation and (C) rates of Leu incorporation, and during February 1991 of (D) cell abundance, (E) rates of TdR incorporation and (F) rates of Leu incorporation 

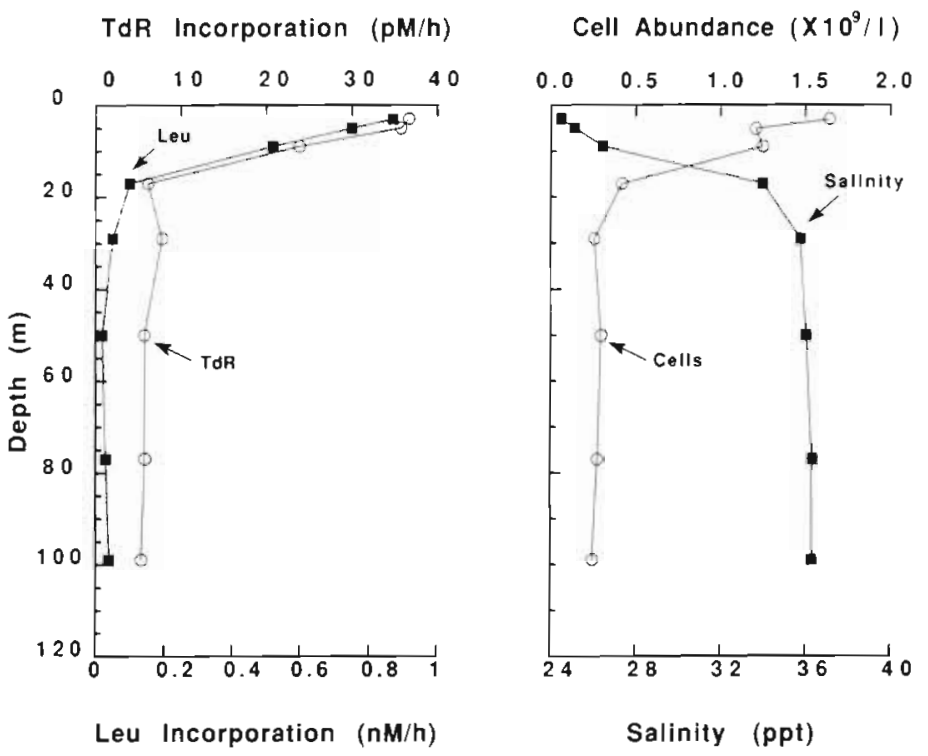

Fig. 4. Vertical profiles of (A) rates of TdR and Leu incorparation and (B) bacterial abundance and salinity at Station J $\left(28^{\circ} 50.6^{\prime} \mathrm{N}, 89^{\circ} 10.8^{\prime} \mathrm{W}\right)$ during July 1990

\section{Depth profiles}

Samples were collected at several depths at various locations on the Louisiana continental shelf and slope, the Mississippi Canyon and the open Gulf of Mexico. The depth of the water columns sampled ranged from 18 to $100 \mathrm{~m}$ on the shelf and 500 to $900 \mathrm{~m}$ over the slope and the open Gulf of Mexico. In shelf waters, near the Mississippi River delta, there were sharp horizontal and vertical gradients of salinity. A typical vertical profile of bacterial parameters and salinity in shelf waters is shown in Figure 4. Bacterial abundance and rates of TdR and Leu incorporation were maximal in surface waters, decreased rapidly to the depth of the halocline and remained relatively constant to the bottom (Fig. 4). Rates of TdR and Leu incorporation generally paralleled each other with depth (Fig. 4). The correlation coefficients between all measurements of TdR and Leu (surface and subsurface waters) was $r=0.90(\mathrm{n}=71$, $p=0.0001)$ in summer and $r=0.72(n=60, p=0.0001)$ in winter. Subsurface particle maxima were frequently detected, but there were no clear trends between the location of these features and the vertical distribution of bacterial abundance or production.

The water column became nearly isohaline in slope and open gulf waters and density stratification was primarily determined by temperature. Bacterial abundance and production were lower in offshore surface waters than in shelf waters, and also decreased with depth. Water samples from below $100 \mathrm{~m}$ were also collected and analyzed, and rates of $\mathrm{TdR}$ and Leu incorporation in deeper waters were similar to those for samples collected near the pycnocline. However, these deep water samples were not incubated at in situ temperatures and pressures and, therefore, these data are not reported.

\section{Depth-integrated bacterial production}

Experiments were conducted to determine conversion factors for estimating rates of bacterial production from rates of $T d R$ incorporation. Empirically-determined conversion factors were $1.59 \times 10^{18}$ and $2.18 \times 10^{18} \mathrm{cells} \mathrm{mol}^{-1} \mathrm{TdR}$ incorporated $\left(\right.$ mean $=1.89 \times 10^{18}$ cells mol $\left.{ }^{-1}\right)$. Rates of Leu incorporation and the bacterial $\mathrm{C}$ conversion factor ( $3.1 \mathrm{~kg} \mathrm{C} \mathrm{mol}{ }^{-1}$ Leu) given by Simon \& Azam (1989) yielded values that were in general agreement with estimates computed using rates of $T d R$ incorporation and the empirically determined conversion factor (Table 1). The mean ratio of bacterial production based on the TdR method to the corresponding value obtained using the Leu method was $1.02 \pm 0.32$ during summer and $0.81 \pm 0.17$ in winter.

During summer, integrated bacterial C production on the shelf based on $T d R$ incorporation varied from 238 to $740 \mathrm{mg} \mathrm{C} \mathrm{m}^{-2} \mathrm{~d}^{-1}$ (mean $=443 \pm 144 \mathrm{mg} \mathrm{C} \mathrm{m}^{-2} \mathrm{~d}^{-1}$ ) (Table 1). Winter values were lower than summer values and ranged from 102 to $363 \mathrm{mg} \mathrm{C} \mathrm{m}^{-2} \mathrm{~d}^{-1}$ (mean $=226 \pm$ $124 \mathrm{mg} \mathrm{C} \mathrm{m}^{-2} \mathrm{~d}^{-1}$ ) (Table 1).

\section{Nutrient enrichment experiments and effects of plume water additions to bacterial production in shelf waters}

During both cruises concentrations of inorganic nutrients in surface waters decreased with increasing salinity. In summer, nutrient concentrations were as high as $48 \mu \mathrm{M} \mathrm{NO}_{3}{ }^{-}$and $0.60 \mathrm{MM} \mathrm{PO}_{4}{ }^{-3}$, at $16 \%$. At salinities $>25 \%$ most samples had nutrient concentration that were below the limits of detection of the autoanalyzer $\left(0.40\right.$ of $\mathrm{NO}_{3}{ }^{-}$and $0.05 \mu \mathrm{M} \mathrm{PO}_{4}{ }^{-3}$ respectively) (G. Berberian unpubl.). Samples for inorganic nutrient concentrations in low salinity $(<16 \%)$ waters were not collected. Typical summer values for $\mathrm{NO}_{3}{ }^{-}$and for $\mathrm{PO}_{4}{ }^{3-}$ near the mouth of Southwest Pass (salinities of 2 to $4 \%$ ) are $93 \mu \mathrm{M}$ and $7 \mu \mathrm{M}$, respectively ( $\mathrm{T}$. Whitledge pers. comm.). In winter, $\mathrm{NO}_{3}{ }^{-}$and $\mathrm{PO}_{4}{ }^{3-}$ concentrations near the outflow of the river (salinities of 2 to $15 \%$ ) were as high as 74 and $7 \mu \mathrm{M}$ respectively (G. Berberian unpubl.). As in summer, nutrient concentrations decreased rapidly as salinities increased over $16 \%$. However, whereas in summer most nutrient concentrations were below detection limits at salinities $>25 \%$, in winter con- 
Table 1 Depth-integrated bacterial C production on the Louisiana continental shelf. Estimates were calculated using rates of thymidine incorporation and an empirically-determined conversion factor of $1.89 \times 10^{18} \mathrm{cells} \mathrm{mol}^{-1}$ and a biomass value of $20 \mathrm{fg} \mathrm{C} \mathrm{Cell}^{-1}$. Independent estimates of bacterial production were calculated using rates of leucine incorporation and the conversion factor of $3.1 \mathrm{~kg} \mathrm{C} \mathrm{mol}{ }^{-1}$ determined by Simon \& Azam (1989)

\begin{tabular}{|c|c|c|c|c|c|c|c|c|}
\hline \multirow[t]{2}{*}{ Date } & \multirow[t]{2}{*}{ Station } & \multirow{2}{*}{$\begin{array}{l}\text { Latitude } \\
\qquad \text { (N) }\end{array}$} & \multirow{2}{*}{$\begin{array}{l}\text { Longitude } \\
\text { (W) }\end{array}$} & \multirow{2}{*}{$\begin{array}{c}\text { Surface } \\
\text { salinity } \\
(1, \ldots)\end{array}$} & \multirow{2}{*}{$\begin{array}{l}\text { Depth } \\
(m)\end{array}$} & \multicolumn{2}{|c|}{$\begin{array}{c}\text { Integrated bacterial } \\
\text { production }\left(\mathrm{mg} C \mathrm{~m}^{-2} \mathrm{~d}^{-1}\right)\end{array}$} & \multirow[t]{2}{*}{ TdR/Leu } \\
\hline & & & & & & $\mathrm{TdR}$ & Leu & \\
\hline 27 Jul 1990 & $\mathrm{H}-2$ & $2850^{\prime}$ & $89^{\circ} 49^{\prime}$ & 16 & 54 & 588 & 789 & 0.75 \\
\hline $31 \mathrm{Jul}$ & A-2 & $28^{\circ} 53^{\prime}$ & $89^{\circ} 56^{\prime}$ & 18 & 36 & 399 & 591 & 0.67 \\
\hline $29 \mathrm{Jul}$ & $\mathrm{H} 18$ & $28^{\circ} 48^{\prime}$ & $91^{\circ} 31^{\prime}$ & 23 & 21 & 509 & 458 & 1.11 \\
\hline $27 \mathrm{Jul}$ & $\mathrm{H}-8$ & $28^{\circ} 40^{\prime}$ & $90^{\circ} 30^{\prime}$ & 24 & 18 & 362 & 441 & 0.82 \\
\hline $21 \mathrm{Jul}$ & $J$ & $28^{\circ} 50^{\prime}$ & $89^{\circ} 10^{\prime}$ & 24 & 99 & 740 & 719 & 1.03 \\
\hline $29 \mathrm{Jul}$ & $\mathrm{H}-12$ & $28^{\circ} 36^{\prime}$ & $91^{\circ} 00^{\prime}$ & 26 & 21 & 353 & 518 & 0.68 \\
\hline $20 \mathrm{Jul}$ & $\mathrm{H}$ & $29^{\circ} 17^{\prime}$ & $88^{\circ} 52^{\prime}$ & 27 & 36 & 303 & 269 & 1.13 \\
\hline $21 \mathrm{Jul}$ & $\mathrm{K}$ & $28^{\circ} 50^{\prime}$ & $89^{\circ} 22^{\prime}$ & 27 & 63 & 434 & 365 & 1.19 \\
\hline $29 \mathrm{Jul}$ & $\mathrm{H}-20$ & $28^{\circ} 54^{\prime}$ & $91^{\circ} 53^{\prime}$ & 27 & 20 & 238 & 328 & 0.73 \\
\hline $21 \mathrm{Jul}$ & I & $28^{\circ} 55^{\prime}$ & $89^{\circ} 02^{\prime}$ & 28 & 75 & 614 & 374 & 1.64 \\
\hline $29 \mathrm{Jul}$ & $\mathrm{H}-14$ & $28^{\circ} 27^{\prime}$ & $90^{\circ} 59^{\prime}$ & 29 & 55 & 360 & 234 & 1.54 \\
\hline \multirow[t]{2}{*}{$27 \mathrm{Jul}$} & $\mathrm{H}-10$ & $28^{\circ} 18^{\prime}$ & $90^{\circ} 29^{\prime}$ & 29 & 56 & 411 & 457 & 0.90 \\
\hline & & & & & Mean $\pm S D=$ & $443 \pm 144$ & $462 \pm 170$ & $1.02 \pm 0.32$ \\
\hline 23 Feb 1991 & A-1 & $28^{\circ} 54^{\prime}$ & $89^{\circ} 29^{\prime}$ & 6 & 29 & 102 & 148 & 0.69 \\
\hline 26 Feb & $\mathrm{H}-8$ & $28^{\circ} 40^{\prime}$ & $90^{\circ} 29^{\prime}$ & 18 & 17 & 143 & 192 & 0.74 \\
\hline $24 \mathrm{Feb}$ & $\mathrm{MC}$ & $28^{\circ} 41^{\prime}$ & $89^{\circ} 40^{\prime}$ & 21 & 92 & 363 & 487 & 1.07 \\
\hline \multirow[t]{2}{*}{$22 \mathrm{Feb}$} & C & $28^{\circ} 46^{\prime}$ & $89^{\circ} 30^{\prime}$ & 22 & 84 & 299 & 279 & 0.74 \\
\hline & & & & & Mean $\pm \mathrm{SD}=$ & $226 \pm 124$ & $277 \pm 151$ & $0.81 \pm 0.28$ \\
\hline
\end{tabular}

centrations as high as $20 \mu \mathrm{M} \mathrm{NO}_{3}^{-}$and $1.2 \mu \mathrm{M} \mathrm{PO}_{4}{ }^{3-}$ were still measured at these salinities

During summer, nutrient enrichment experiments were conducted with water of salinity 16, 31 and $34 \%$. The concentrations of $\mathrm{NO}_{3}{ }^{-}$and $\mathrm{PO}_{4}{ }^{3-}$ at $16 \%$ were 46.72 and $0.25 \mu \mathrm{M}$ respectively. At $31 \%$, concentrations of $\mathrm{NO}_{3}{ }^{-}$and $\mathrm{PO}_{4}{ }^{3-}$ were lower $(21.15 \mu \mathrm{M}$ and $0.05 \mu \mathrm{M})$, and at $34 \%$, concentrations were below the detection limit of the autoanalyzer. Ammonium concentrations were not measured, but concentrations are typically very low in these waters relative to $\mathrm{NO}_{3}{ }^{-}$concentrations.

The responses of natural bacterial populations to the addition of nutrients and a labile $\mathrm{C}$ source were different at each salinity. In water of $16 \%$ only the treatment with added glucose showed increases in rates of TdR and Leu incorporation over the control (Figs. 5A \& 6A). In water of $31 \%$, the addition of $\mathrm{P}$ (as $\mathrm{PO}_{4}{ }^{3}$ ) singly and $\mathrm{P}$ and $\mathrm{N}$ (as $\mathrm{NO}_{3}{ }^{-}$) jointly $(\mathrm{P}+\mathrm{N})$ increased the incorporation of $\mathrm{TdR}$ and Leu 3-fold over the control in the first $4 \mathrm{~h}$ of the incubation (Figs. 5B \& 6B). Addition of $N$ singly also enhanced TdR and Leu incorporation, but increases were not measured until after 15 h of incubation (Figs. 5B \& 6B). In open gulf water $(34 \%)$ there was no clear difference among treatments in rates of TdR and Leu incorporation, and the incorporation rates remained relatively constant over the course of the experiment (Figs. 5C \& 6C). At the 3 salinities tested, changes in bacterial abundance in the different treatments also differed from the control but differences among treatments were small (Fig. $7 \mathrm{~A}$ to C).
During summer we examined the response of bacterial assemblages in gulf waters to the input of materials from plume waters collected near the discharge of the Mississippi River. Filter-sterilized plume water was added to unfiltered water from the open gulf, and bacterial abundance and production in this water was compared to that in open gulf samples diluted with filter-sterilized gulf water. Treatments with added filtered plume water (16\%) had higher concentrations of DOC and inorganic nutrients. Rates of TdR and Leu incorporation increased after $8 \mathrm{~h}$ in replicate samples spiked with plume water (Fig. 8A, B). Bacterial abundance increased in these treatments over the control after $22 \mathrm{~h}$. It is not clear from this experiment what materials in the plume water were responsible for the enhancement in bacterial growth, but it is evident that riverine-derived substrates enhanced the heterotrophic activity in gulf waters.

In winter, nutrient enrichment experiments were repeated with water of $0,18,21$ and $34 \%$. The concentrations of $\mathrm{NO}_{3}{ }^{-}$and $\mathrm{PO}_{4}{ }^{3-}$ were 108.1 and $0.25 \mu \mathrm{M}$ at $0 \%$, 42.31 and $0.72 \mu \mathrm{M}$ at $18 \%$, 4.48 and $0.21 \mu \mathrm{M}$ at $21 \%$, and below the detection limit of the autoanalyzer at $34 \%$. In these experiments, bacterial abundance and production were lower than in summer ( $>4$-fold). There were no clear differences in the variations of bacterial abundance or production among treatments (Fig. 9). For example, with the exception of shelf waters $(34 \%$ ) where $\mathrm{P}+\mathrm{N}$ additions enhanced TdR incorporation rates, TdR incorporation among the various salinities did not show any clear differences. 

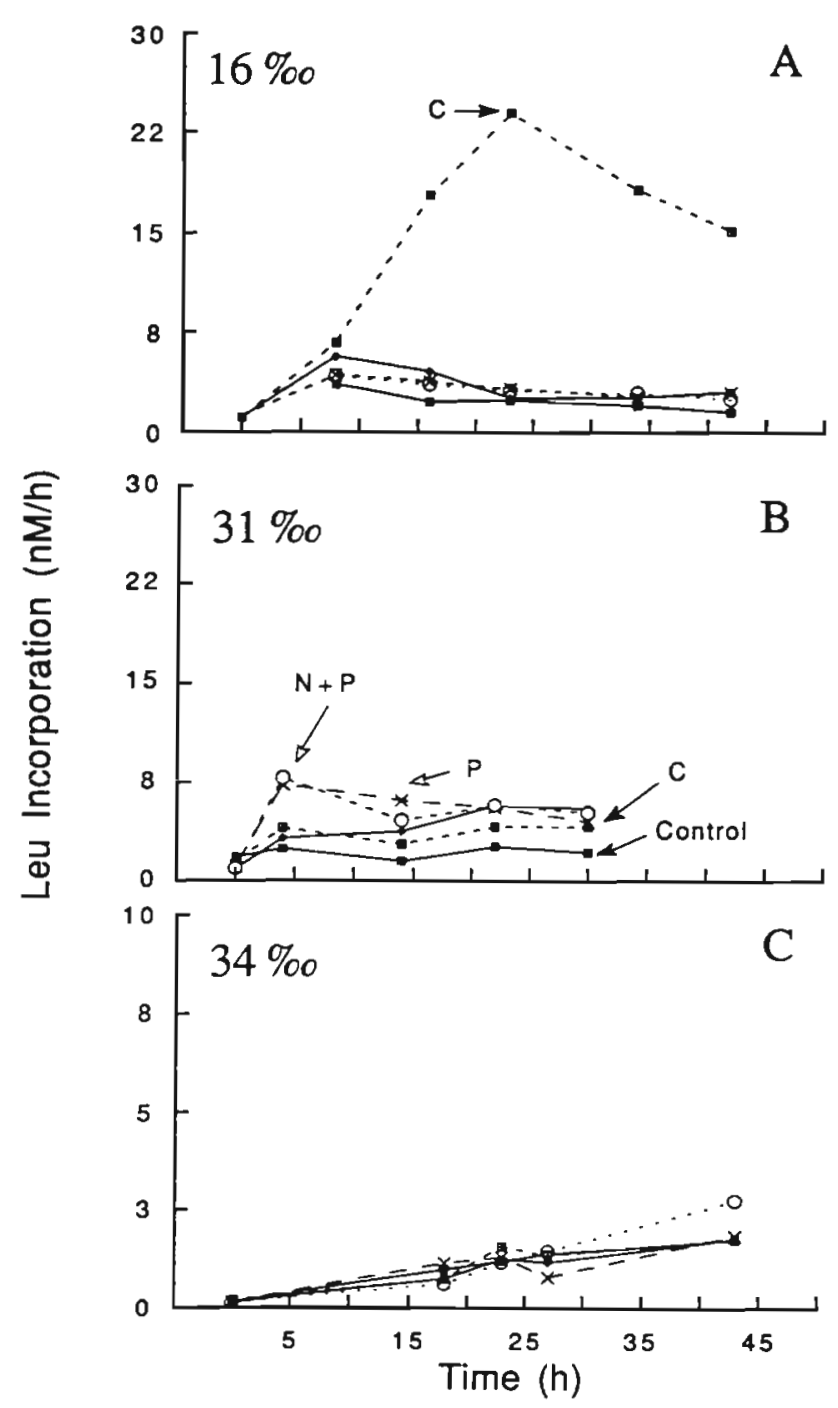

Fig. 5. Nutrient addition experiments performed in July and August 1990 in water of (A) $16 \%$, (B) $31 \%$ and (C) $34 \%$ salinity. Plots show the variation over time of rates of Leu incorporation in samples amended with glucose (C), $\mathrm{NH}_{4} \mathrm{Cl}$ (N), $\mathrm{KH}_{2} \mathrm{PO}_{4}(\mathrm{P})$ and both $\mathrm{NH}_{4} \mathrm{Cl}$ and $\mathrm{KH}_{2} \mathrm{PO}_{4}(\mathrm{~N}+\mathrm{P})$. The scale in $(\mathrm{C})$ was changed so that the rates of incorporation could be visualized

\section{Bacterial growth efficiencies}

In summer, bacterial growth efficiency was determined using water of $16.7,17.4$ and $23.1 \%$ salinity, In these experiments, rates of bacterial production ranged from 0.62 to $3.17 \mu \mathrm{M} \mathrm{C} \mathrm{d}{ }^{-1}$, and rates of $\mathrm{DO}$ consumption varied from 4.62 to $22.23 \mu \mathrm{M} \mathrm{O}_{2} \mathrm{~d}^{-1}$. The mean bacterial growth efficiency was $16 \pm 9 \%$ and $24 \pm 14 \%$ using rates of $\mathrm{TdR}$ and Leu incorporation, respectively. In winter, bacterial growth efficiencies were determined in water of $0,17.0,28.3$ and $34 \%$ salinity. Rates of bacterial production and of DO con-
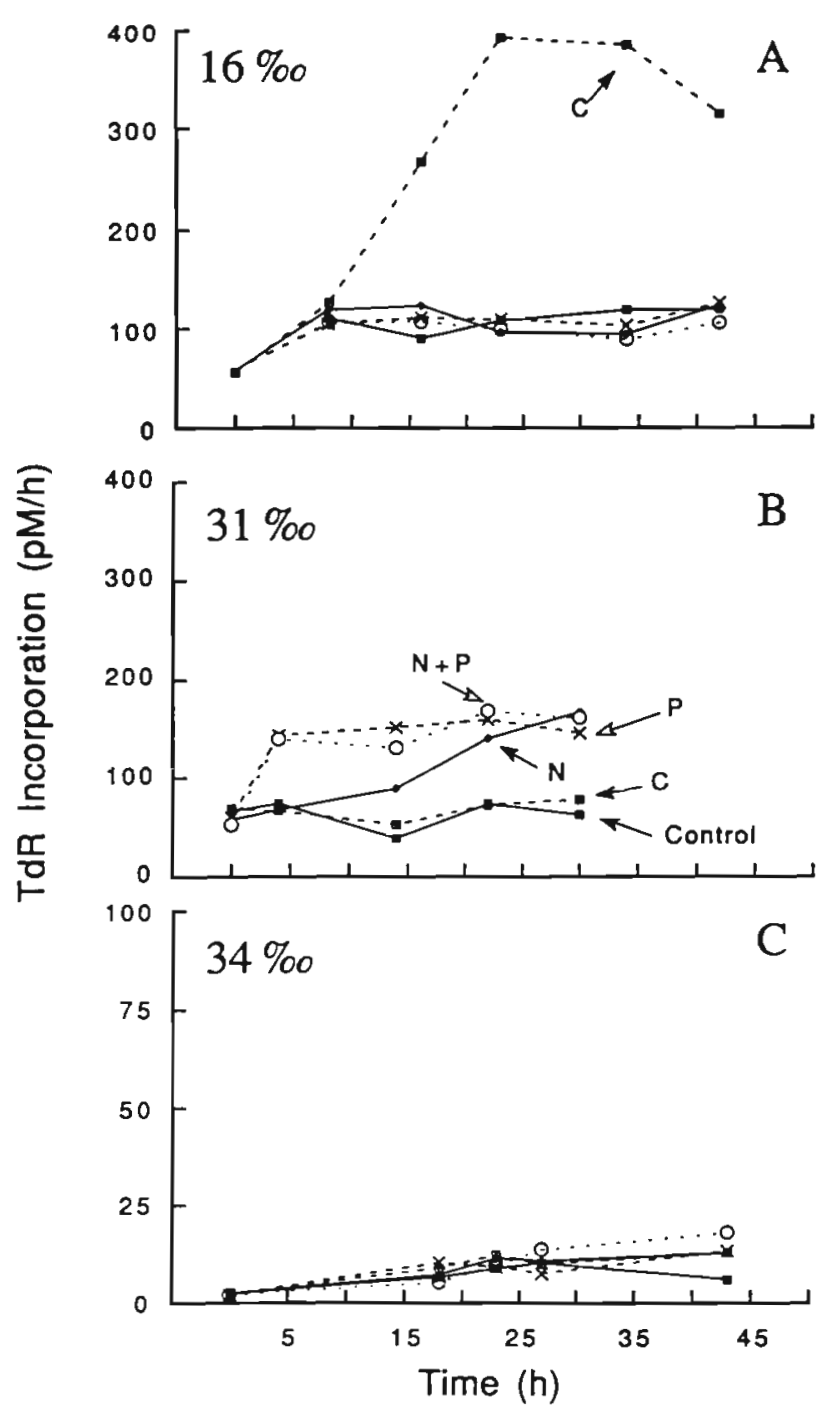

Fig. 6. Same as Fig. 5 but for rates of TdR incorporation

sumption were lower than in summer ranging from 0.55 to $2.67 \mu \mathrm{M} \mathrm{C} \mathrm{d}^{-1}$, and from 1.10 to $9.33 \mu \mathrm{M} \mathrm{O}_{2} \mathrm{~d}^{-1}$. Mean values of bacterial growth efficiency in winter were higher and less variable than in summer (Table 2). In winter, growth efficiencies derived from TdR data were remarkably uniform $(22 \pm 1 \%)$. The Leu-derived value was $32 \pm 8 \%$. We used the overall mean of $19 \pm 6(n=7)$ for TdR-based values and of $29 \pm$ $11(n=7)$ for Leu-based values to estimate the amount of $\mathrm{C}$ needed to support bacterial production.

\section{Plankton community respiration}

Rates of plankton community respiration were measured during February 1991 in waters of various salinities. Rates of oxygen utilization ranged from 1.47 to $19.7 \mu \mathrm{M} \mathrm{O}_{2} \mathrm{~d}^{-1}$ (mean $=9.23 \pm 5.99 \mu \mathrm{M} \mathrm{O} \mathrm{O}^{-1}$ ) 


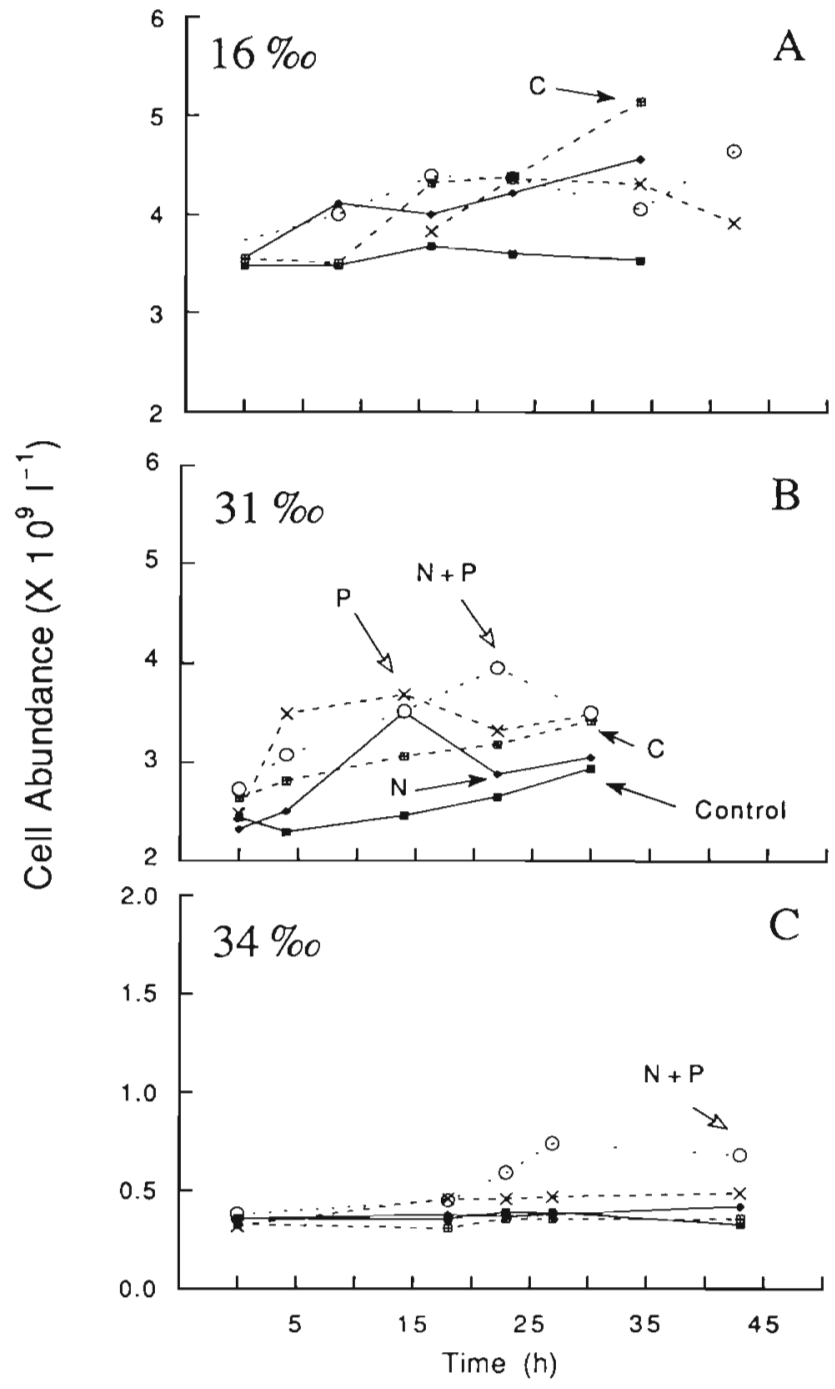

Fig. 7. Same as Fig. 6 but for bacterial abundance

(Table 3). Respiration rates were maximal at intermediate salinities ( 18 to $24 \%$ ). The high sediment load near the river interfered with the automated colorimetric detection of the end point, and reproducible estimates of respiration rates from salinities $<6 \%$ could not be determined. Rates of oxygen utilization by bacteria derived from the growth efficiency experiments (Table 2; February experiments) were within a factor of 2 of rates of plankton community respiration (Table 3). Assuming these rates are comparable (the incubation periods and the volume of the bottles were different), these data indicate that bacteria contributed significantly to the total oxygen demand.

Rates of TdR and Leu incorporation were measured simultaneously in replicate water samples to determine the relationship between bacterial production and community respiration. At salinities ranging from
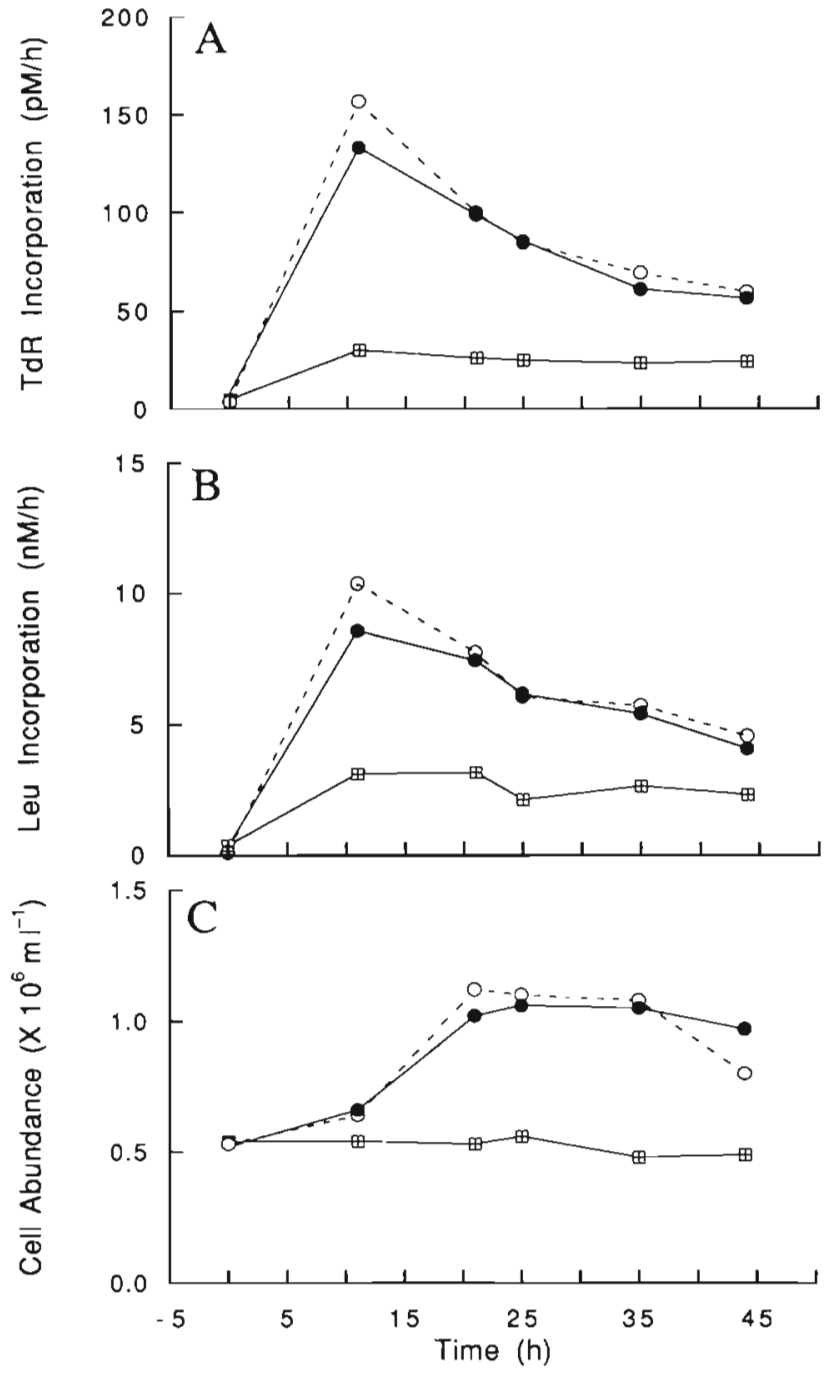

Fig. 8. Effects of plume water additions on (A) rates of TdR incorporation, (B) rates of Leu incorporation and (C) bacterial abundance in water from the open Gulf during summer 1990. $(0,-)$ Values in duplicate treatments where $0.2 \mu \mathrm{m}$ filtered water of $16 \%$ was mixed with unfiltered $36 \%$ water; $($ 由) values in the control experiment where $0.2 \mu \mathrm{m}$ filtered water of $36 \%$ was mixed with unfiltered $36 \%$ water

6 to $36 \%$, values of bacterial production estimated from rates of TdR or Leu incorporation were generally in good agreement (Table 3). Rates of community oxygen utilization were not significantly correlated to rates of TdR incorporation $(r=0.25, p=0.420)$ or to rates of Leu incorporation $(r=0.43, p=0.138)$.

\section{Fractionation of ${ }^{3} \mathrm{H}$ into protein and DNA fractions}

All samples were treated to separate the DNA and protein fractions. Most (> $90 \%$ ) of the Leu was specifically incorporated into protein. In contrast, 


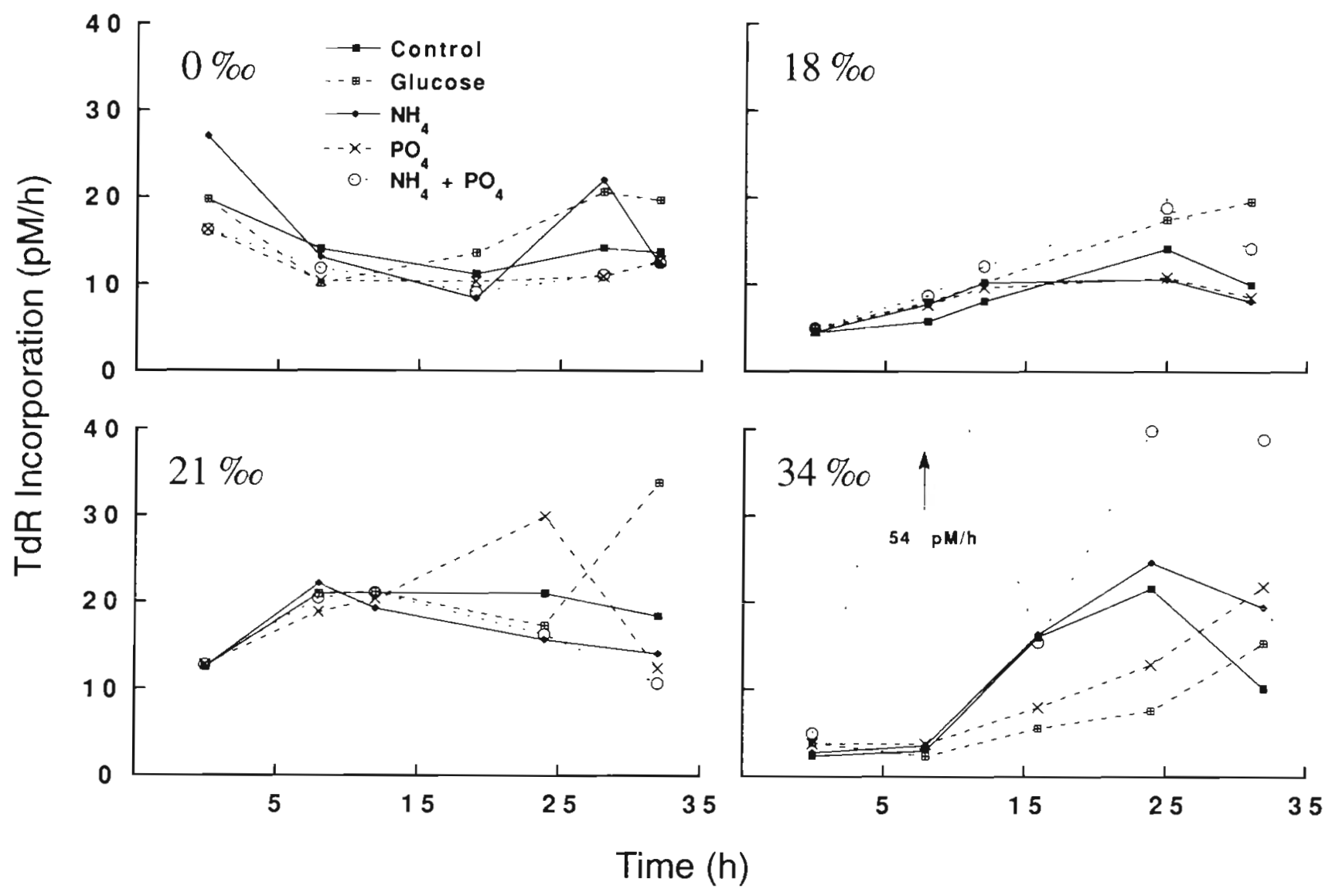

Fig. 9. Nutrient addition experiments performed in February 1991 in water of $0,18,21$ and $34 \%$. Plots show the variation over time at each salinity of rates of TdR incorporation in water with no additions (control) and water amended with glucose $(\mathrm{G}), \mathrm{NH}{ }_{4} \mathrm{Cl}(\mathrm{N})$, $\mathrm{KH}_{2} \mathrm{PO}_{4}(\mathrm{P})$ and both $\mathrm{NH}_{4} \mathrm{Cl}$ and $\mathrm{KH}_{2} \mathrm{PO}_{4}(\mathrm{~N}+\mathrm{P})$. (Key to symbols in all plots is in the $0 \%$ plot)

Table 2. Bacterial growth efficiencies calculated during summer 1990 and winter 1991 using water of various salinities. Bacterial growth efficiency was defined as the ratio between $C$ production and the sum of $C$ production and $C$ respiration $(E=$ production $\div$ (production + respiration)). Bacterial C production was estimated from daily rates of TdR and Leu incorporation integrated over the course of the experiment using an empirically-derived conversion factor of $1.89 \times 10^{18} \mathrm{cells} \mathrm{mol}^{-1}$ and a biomass value of $20 \mathrm{fg} \mathrm{C}$ cell ${ }^{-1}$ for $\mathrm{TdR}$ and a factor of $3.1 \mathrm{~kg} \mathrm{C} \mathrm{mol}^{-1}$ determined by Simon \& Azam (1989) for Leu. C respiration was estimated from rates of oxygen consumption assuming a respiratory quotient $\left(\mathrm{RQ}=\Delta \mathrm{CO}_{2} / \Delta \mathrm{O}_{2}\right.$ ) of 1 . Bacterial growth efficiency is reported as a percentage

\begin{tabular}{|c|c|c|c|c|c|c|c|c|}
\hline \multirow[t]{2}{*}{ Date } & \multirow[t]{2}{*}{$\begin{array}{l}\text { Salinity } \\
(\% 0)\end{array}$} & \multirow[t]{2}{*}{$\begin{array}{l}\text { Temperature } \\
\left({ }^{\circ} \mathrm{C}\right)\end{array}$} & \multirow[t]{2}{*}{$\begin{array}{l}\text { Experiment } \\
\text { duration (h) }\end{array}$} & \multicolumn{2}{|c|}{$\begin{array}{l}\text { Integrated bacterial } \\
\text { production }(\mu \mathrm{M} C)\end{array}$} & \multirow[t]{2}{*}{$\begin{array}{l}\mu \mathrm{MC} \text { respired } \\
\text { efficiency }(\%)\end{array}$} & \multicolumn{2}{|c|}{ Bacterial growth } \\
\hline & & & & $T d R$ & Leu & & $T d R$ & Leu \\
\hline $21-24$ Jul 1990 & 16.7 & 28 & 72 & 9.5 & 6.8 & 66.7 & 13 & 9 \\
\hline $25-29 \mathrm{Jul}$ & 17.4 & 28 & 96 & 6.6 & 11.0 & 18.5 & 26 & 37 \\
\hline \multirow[t]{2}{*}{$20 \mathrm{Jul}-3$ Aug } & 23.1 & 31 & 120 & 3.1 & 9.8 & 28.6 & 10 & 26 \\
\hline & & & & & & \multicolumn{2}{|c|}{ Mean $\pm S D=16 \pm 9$} & $24 \pm 14$ \\
\hline 24-26 Feb 1991 & 0.2 & 9 & 72 & 2.7 & 7.0 & 9.8 & 22 & 42 \\
\hline $23-25$ Feb & 17.0 & 16 & 44 & 4.9 & 6.8 & 17.1 & 22 & 29 \\
\hline $26-28 \mathrm{Feb}$ & 28.3 & 17 & 49 & 3.0 & 5.3 & 10.8 & 22 & 33 \\
\hline \multirow[t]{2}{*}{$21-23$ Feb } & 34.0 & 20 & 48 & 1.1 & 1.4 & 4.4 & 21 & 24 \\
\hline & & & & & & \multicolumn{2}{|c|}{ Mean $\pm S D=22 \pm 1$} & $32 \pm 8$ \\
\hline
\end{tabular}


Table 3. Comparison along a salinity gradient of community respiration and bacterial production estimated from rates of thymidine and leucine incorporation

\begin{tabular}{|c|c|c|c|c|c|c|c|}
\hline \multirow[t]{2}{*}{$\begin{array}{l}\text { Date } \\
(1991)\end{array}$} & \multirow[t]{2}{*}{ Station } & \multirow{2}{*}{$\begin{array}{l}\text { Latitude } \\
\qquad(\mathrm{N})\end{array}$} & \multirow{2}{*}{$\begin{array}{l}\text { Longitude } \\
\text { (W) }\end{array}$} & \multirow{2}{*}{$\begin{array}{c}\text { Salinity } \\
(\% \infty)\end{array}$} & \multirow{2}{*}{$\begin{array}{c}\text { Community } \\
\text { respiration } \\
\left(\mu \mathrm{MO}_{2} \mathrm{~d}^{-1}\right)\end{array}$} & \multicolumn{2}{|c|}{$\begin{array}{l}\text { Bacterial production } \\
\qquad\left(\mu \mathrm{M} \mathrm{Cd}^{-1}\right)\end{array}$} \\
\hline & & & & & & $\mathrm{TdR}^{0}$ & Leu $^{b}$ \\
\hline $24 \mathrm{Feb}$ & Small boat survey $(0.5 \mathrm{~m})$ & $28^{\circ} 53^{\prime}$ & $89^{\circ} 30^{\prime}$ & 6 & 4.73 & 0.38 & 0.64 \\
\hline $23 \mathrm{Feb}$ & Anchor-1 (1 m) & $28^{\circ} 54^{\prime}$ & $89^{\circ} 30^{\prime}$ & 18 & 10.67 & 1.26 & 2.76 \\
\hline $27 \mathrm{Feb}$ & Anchor-2 (1 m) & $28^{\circ} 54^{\prime}$ & $89^{\circ} 56^{\prime}$ & 21 & 9.55 & 1.55 & 2.75 \\
\hline $22 \mathrm{Feb}$ & $\mathrm{L}(1 \mathrm{~m})$ & $28^{\circ} 00^{\prime}$ & $89^{\circ} 59^{\prime}$ & 21 & 14.28 & 1.26 & 0.65 \\
\hline $22 \mathrm{Feb}$ & $K(1 \mathrm{~m})$ & $28^{\circ} 50^{\prime}$ & $89^{\circ} 22^{\prime}$ & 22 & 16.20 & 0.79 & 0.31 \\
\hline $22 \mathrm{Feb}$ & $\mathrm{I}(1 \mathrm{~m})$ & $28^{\circ} 55^{\prime}$ & $89^{\circ} 02^{\prime}$ & 24 & 19.69 & 0.34 & 0.50 \\
\hline 25 Feb & HT-12 (5 m) & $28^{\circ} 27^{\prime}$ & $90^{\circ} 58^{\prime}$ & 29 & 7.23 & 1.68 & 3.59 \\
\hline $25 \mathrm{Feb}$ & $\mathrm{HT}-12(20 \mathrm{~m})$ & $28^{\circ} 27^{\prime}$ & $90^{\circ} 58^{\prime}$ & 34 & 2.95 & 0.64 & 0.78 \\
\hline $22 \mathrm{Feb}$ & $\mathrm{C}(6 \mathrm{~m})$ & $28^{\circ} 47^{\prime}$ & $89^{\circ} 30^{\prime}$ & 36 & 5.54 & 0.36 & 0.25 \\
\hline $22 \mathrm{Feb}$ & $\mathrm{C}(48 \mathrm{~m})$ & $28^{\circ} 47^{\prime}$ & $89^{\circ} 30^{\prime}$ & 36 & 1.47 & 0.29 & 0.24 \\
\hline
\end{tabular}

significant amounts of ${ }^{3} \mathrm{H}$ from methyl-labeled TdR were recovered in the protein as well as DNA fractions. In surface waters, the amount of ${ }^{3} \mathrm{H}$ found in the protein fraction varied over the salinity gradient. In both cruises, the percentage of radioactivity from TdR recovered in the protein fraction decreased with increasing salinity and ranged from $74 \%$ in river water to $8 \%$ in ocean water (Fig. 10). This trend of decreasing $\mathrm{TdR}$ metabolism with increasing

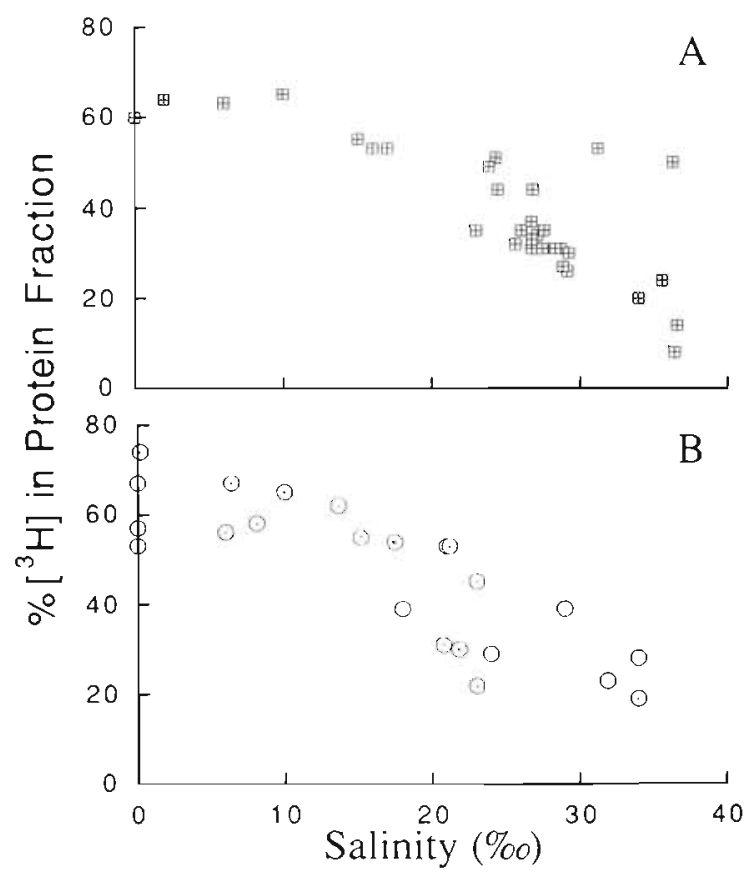

Fig. 10. Plots of the \% TdR incorporated into the protein fraction along a salinity gradient in surface waters from 0 to $36 \%$ during (A) July-August 1990 and (B) February 1991 salinity was also observed over all depth profiles even in water columns with hypoxic bottom waters $\left(<1 \mathrm{ml} \mathrm{l}^{-1}\right)$. All the incorporation measurements were corrected for abiotic absorption, and it is therefore unlikely that the radioactivity in the protein fraction was due to the adsorption of TdR to particles at low salinities.

\section{DISCUSSION}

\section{Distribution of bacterial production along a salinity gradient}

Bacterial production in the Mississippi River plume ranged from 5 to $90 \mu \mathrm{g} \mathrm{C} \mathrm{l}^{-1} \mathrm{~d}^{-1}$, respectively. These values are high when compared to values measured in the plumes of 3 rivers in the Strait of Georgia (Canada) (0 to $12 \mu \mathrm{g} \mathrm{Cl}^{-1} \mathrm{~d}^{-1}$ : Albright 1983) and in the plume of the Rhône River (France) $\left(0.24\right.$ to $7.2 \mu \mathrm{g} \mathrm{C} \mathrm{l}^{-1} \mathrm{~d}^{-1}$ : Kirchman et al. 1989), but similar to values reported from estuaries such as Delaware Bay (USA) (5 to $38 \mu \mathrm{g}$ $\mathrm{Cl}^{-1} \mathrm{~d}^{-1}$ : Coffin \& Sharp 1987, Kirchman \& Hoch 1988) and Chesapeake Bay (USA) (20 to $280 \mu \mathrm{g} \mathrm{C}^{-1} \mathrm{~d}^{-1}$ : Jonas \& Tuttle $1990 ; 4$ to $50 \mu \mathrm{g} \mathrm{C} \mathrm{l}^{-1} \mathrm{~d}^{-1}$ : Malone \& Ducklow 1990).

Bacterial production was maximal at salinities between 15 and $30 \%$ during both summer and winter. In winter, plankton community respiration as well as rates of bacterial production were enhanced at these intermediate salinities indicating greater overall heterotrophic activity in the plume than in river water or in open waters of the gulf. Hanson (1982) also found high levels of bacterial activity (estimated using $\left[{ }^{14} \mathrm{C}\right]$ glucose uptake) and of particulate organic carbon (POC) in plume waters between 20 to $30 \%$. These 
intermediate salinities in the Mississippi River plume are also characterized by high biomass and activity of autotrophic organisms. Lohrenz et al. (1990) measured elevated concentrations of both chlorophyll a and rates of phytoplankton production at salinities between 15 and $30 \%$ during spring 1988 . Relatively high primary production values were also found in plume waters during 1990 (Redalje et al, 1992). The finding that maximal values of both bacterial and phytoplankton production occur at intermediate salinity suggests that bacterial growth is primarily regulated by phytoplankton-derived substrates. In this study, bacterial and phytoplankton production were not measured concurrently and a direct comparison could not be made. However, we compared bacterial production to chlorophyll a values that were obtained from many of our samples. The correlation between chlorophyll a and bacterial production (TdR and Leu incorporation) during the summer of 1990 in surface waters between 2 and $31 \%$ was not significant ( $T d R, p=0.2410$; Leu, $\mathrm{p}=0.2077$ ). However, if biomass reflects production, this comparison could yield information on the relative dependence of bacteria on phytoplankton-derived organic matter. Lohrenz et al. (1990) found that high chlorophyll a levels in the plume reflected high rates of primary production.

Albright et al. (1983) and Kirchman et al. (1989) found that at intermediate salinities bacterial and phytoplankton production were poorly correlated in the plume of rivers in the Strait of Georgia and in the plume of the Rhone River. This discrepancy from the strong relationship frequently found between bacteria and phytoplankton in most marine ecosystems (Bird \& Kalff 1984, Cole et al. 1988, White et al. 1991) appears to result from bacterial utilization of substrates introduced by rivers in addition to those produced in situ by phytoplankton.

The poor correlation between bacterial production and phytoplankton biomass in the Mississippi River plume suggests that organic matter introduced into the gulf by the river may be important in supporting bacterial growth. Approximately $4 \times 10^{12} \mathrm{~g} \mathrm{C}$ (POC + DOC) are discharged annually into the Gulf of Mexico by the Mississippi (MaIcolm \& Durum 1976). Although riverine $D O C$ is considered to be resistant to microbial utilization, bacterial production in river water was substantial, and rates of bacterial production in open gulf waters were enhanced by additions of low salinity plume water $(16 \%)$ suggesting that riverine substrates were not entirely refractory. In addition, materials discharged by the river may undergo photochemical transformations that increase their availability to bacteria. Kieber et al. $(1989,1990)$ found that photochemical degradation of biologically refractory dissolved organic matter (DOM) produced compounds that could be rapidly utilized by bacteria. Photo-oxidation of riverine materials may be particularly significant at intermediate salinities in the Mississippi River plume owing to the decreased sediment load and enhanced light penetration.

The relative importance of riverine substrates in supporting bacterial production versus those derived from phytoplankton can be estimated by assuming that bacterial production at low salinities is supported exclusively by rivenine sources and that these substrates are not depleted in the plume. The increase in bacterial production in the plume over that near the river should then represent the fraction of total bacterial production supported by phytoplankton-derived substrates. In summer, bacterial production was relatively constant at salinities $<10 \%$ and averaged 9.87 $\pm 1.95 \mu \mathrm{g} \mathrm{C} \mathrm{l}^{-1} \mathrm{~d}^{-1}$. At intermediate salinities (15 to $30 \%$ ) mean bacterial production increased 3 -fold to $30.7 \pm 20.4 \mu \mathrm{g} \mathrm{C} \mathrm{l}^{-1} \mathrm{~d}^{-1}$. Using this simple model, we estimate that $68 \%$ of the bacterial production in the plume was supported by phytoplankton-derived substrates in summer. In winter, the average bacterial production at salinities $<10 \%\left(8.4 \pm 3.8 \mu \mathrm{g} \mathrm{C} \mathrm{l}^{-1} \mathrm{~d}^{-1}\right)$ was similar to that at intermediate salinities (10.2 \pm $5.8 \mu \mathrm{g} \mathrm{C}^{-1} \mathrm{~d}^{-1}$ ) and phytoplankton-derived substrates only contributed to $18 \%$ of the bacterial production in the plume. This decrease in the contribution of phytoplankton-derived substrates for bacterial production in winter was consistent with the decreased rates of phytoplankton production at this time (Redalje et al 1992). Although rates of bacterial production varied between summer and winter at intermediate salinities, there was little variability in rates of bacterial production in river and open gulf waters between these seasons.

In summer, the responses of bacteria to nutrient enrichments indicated that as salinity increased different elements became limiting for bacterial growth. At $16 \%$ bacterial growth was enhanced by additions of organic C suggesting that bacteria were $C$ limited. Bacterial growth at $31 \%$ was not enhanced by organic $\mathrm{C}$ alone but was enhanced by $\mathrm{PO}_{4}{ }^{3-}$ and by $\mathrm{NH}_{4}{ }^{+}$. These variations in the responses of bacteria to nutrient enrichments probably reflect variations in the quality and availability of substrates as salinity increases. At low salinities, N, P and $C$ are in large supply, but $C$ may be relatively refractory. At intermediate salinities the increase in phytoplankton biomass and production is likely to increase the supply of labile $C$ but also decreases the availability of $N$ and $P$. Therefore, $\mathrm{N}$ and $\mathrm{P}$ are likely to be limiting at intermediate salinities. $P$ appears to be a particularly important limiting element at these salinities. Additions of $\mathrm{PO}_{4}{ }^{3-}$ singly or with $\mathrm{NH}_{4}{ }^{+}$enhanced bacterial growth faster than additions of $\mathrm{NH}_{4}{ }^{+}$singly. Rapid 
turnover rates of $\mathrm{PO}_{4}{ }^{3-}$ were recently measured in the Mississippi River plume (Ammerman 1992) also suggesting the potential importance of $\mathrm{P}$ as a limiting nutrient for bacteria in this system. $\mathrm{P}$ is an important limiting element in freshwater systems and enhancement of bacterial production following $\mathrm{P}$ additions has been reported (Toolan et al. 1991).

In the winter nutrient enrichment experiments, rates of bacterial production were over 4 -fold lower than in summer. Bacterial assemblages did not respond to enrichments at low $(0 \%)$ or intermediate ( 18 and $21 \%$ ) salinities suggesting that bacteria were not limited by any of the added elements. Concentrations of $\mathrm{NO}_{3}{ }^{-}$ and $\mathrm{PO}_{4}{ }^{3-}$ at salinities $>20 \%$ were generally higher in winter than in summer and bacterial growth may not have been constrained by the availability of these nutrients. The reduced response to glucose additions in river water was unexpected. In winter, bacteria may be temperature limited rather than substrate limited. At lower salinities where water temperatures were low this limitation would have been especially important.

\section{Metabolism of TdR by bacteria}

The rate of TdR incorporation into DNA has become a widely used method to measure bacterial production, but the specificity of TdR incorporation into DNA has been questioned. A substantial amount of the TdR incorporated into macromolecules is often recovered in the protein fraction (Hollibaugh 1988, Robarts \& Wicks 1989) and the amount of TdR that is metabolized and incorporated into macromolecules other than DNA can vary with location and environmental conditions (Robarts et al. 1986, Smits \& Riemann 1988). In the present study, TdR incorporation into protein was negatively correlated with salinity during summer and winter $(p=0.0001)$.

From the various studies that reported the percentage of TdR incorporated into protein there does not appear to be a consistent difference between values obtained in fresh and marine waters. Riemann \& Søndergaard (1984) found greater TdR incorporation into protein in freshwater ( 20 to $40 \%$ ) than in marine waters (0 to $26 \%$ ). Kirchman \& Hoch (1988), during a survey of the salinity gradient in Delaware Bay, found no relationship between time of sampling or location and the amount of TdR that was incorporated into protein (30 to $100 \%)$. In a shallow, hypersaline lagoon (33 to $55 \%$ ) over an 18 mo period, Chin-Leo \& Benner (1991) measured a relatively constant percentage $(40 \pm 3 \%)$ of radiolabel from $\mathrm{TdR}$ in the protein fraction.

In the present study, it is unlikely that changes in salinity were directly responsible for the variation in
TdR metabolism. Factors that covary with salinity and are related to the physiological status of bacteria or to variations in the species composition of the bacterial assemblage are more likely explanations. We found that bacterial production was limited by the availability of $\mathrm{C}$ in low salinity waters $(16 \%)$. Bacteria whose growth is limited by the availability of $\mathrm{C}$ may catabolize TdR, whereas bacteria not limited by these substrates may incorporate TdR primarily into DNA. Hanson \& Lowery (1983) found that bacteria in surface waters incorporated up to $98 \%$ of the added $\left[^{3} \mathrm{H} \mid \mathrm{TdR}\right.$ into DNA, whereas in deep-sea waters where much of the organic $\mathrm{C}$ is thought to be refractory, up to $80 \%$ of the label was recovered in protein.

\section{Estimating bacterial $\mathrm{C}$ production from TdR and Leu incorporation rates}

Rates of Leu incorporation have been used as an independent measure of bacterial production (Kirchman et al. 1985), and rates of TdR and Leu incorporation have been reported to covary in a variety of aquatic systems (McDonough et al. 1986, Kirchman \& Hoch 1988, Chin-Leo \& Benner 1991). In the present study, rates of TdR and Leu incorporation were significantly correlated $(p=0.0001)$ during summer and winter. The good correspondence between these independent measurements indicates that variations in bacterial production were not caused by artifacts of either method (e.g. isotope dilution). The Leu method positively complements the TdR method and can be used as an alternative to the TdR method. Moreover, the Leu method has some advantages over the TdR method. Leu appears to be specifically incorporated into protein, and therefore the Leu method does not require a procedure to separate the nucleic acid and protein fractions. In addition, bacterial $\mathrm{C}$ production can be directly estimated from rates of protein synthesis (Leu incorporation) because cell protein : carbon is constant (Simon \& Azam 1989). Using the Leu method, there is no need to derive a factor to convert incorporation rates to cells produced. TdR incorporation rates provide estimates of rates of cell division and knowledge of the amount of $C$ per cell is needed to estimate bacterial $\mathrm{C}$ production.

We estimated bacterial $\mathrm{C}$ production from rates of TdR incorporation using conversion factors determined empirically. The mean empirical conversion factor for

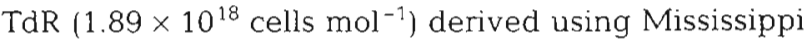
River plume water was in the range reported from batch (Moriarty 1988) and continuous (Ellenbroek \& Cappenberg 1991) cultures. Bacterial C production was estimated from rates of Leu incorporation using the conversion factor of Simon \& Azam (1989) of $3.1 \mathrm{~kg}$ 
C produced $\mathrm{mol}^{-1}$ of Leu incorporated. This conversion factor was derived from experimental determination of the mol\% Leu in protein, the amount of isotope dilution due to de novo synthesis of Leu, the per-cell protein content, the protein:cell volume relationship, and the ratio of cell protein to cell $\mathrm{C}$. We also empirically determined a conversion factor from Leu incorporation to cells produced. The mean empirical conversion factor for Leu $\left(4.46 \times 10^{16}\right.$ cells $\left.\mathrm{mol}^{-1}\right)$ was within the range of values reported in the literature (Chin-Leo \& Kirchman 1988, Kirchman \& Hoch 1988). We chose to use the conversion factor of Simon \& Azam (1989) because the empirically-derived relationship between Leu incorporation and cells produced may not always be adequate since protein synthesis is not directly linked to cell division as is DNA synthesis. Increases in cell size without cell division would produce a Leu empirical conversion factor that underestimates bacterial C production. During summer and winter, estimates of bacterial $C$ production using TdR incorporation and the empirically-derived conversion factor were approximately 3 -fold higher than the corresponding values based on Leu incorporation. The Leu incorporation-to-C conversion factor of Simon \& Azam (1989) gave estimates of bacterial $C$ production that were in better agreement with values based on TdR incorporation.

\section{Plankton community respiration and bacterial production}

Rates of plankton community respiration measured during winter averaged $9.23 \pm 5.99 \mu \mathrm{M} \mathrm{O}_{2} \mathrm{~d}^{-1}$ and were within the range reported by Turner \& Allen (1982b) $\left(0.18\right.$ to $\left.12 \mu \mathrm{M} \mathrm{O}_{2} \mathrm{~d}^{-1}\right)$ from the Mississippi River plume and by Williams (1984) from other coastal waters $\left(0.09\right.$ to $\left.20 \mu \mathrm{M} \mathrm{O}_{2} \mathrm{~d}^{-1}\right)$. Community respiration and rates of bacterial production were enhanced at intermediate salinities indicating greater overall heterotrophic activity in the plume than in river water or in open waters of the gulf. Rates of plankton community respiration were measured only during February, and rates are likely to be higher during summer when water temperatures and rates of primary production are higher.

In this survey, assuming a range of bacterial growth efficiencies from 19 to $29 \%$ (see below), we estimated that bacterial respiration in winter could account for 7 to $93 \%$ of plankton community. Respiration rates in size-fractionated samples were not measured and the fraction of plankton community respiration accounted for by bacteria was not determined directly. However, some estimates of bacterial respiration were obtained from experiments to determine bacterial growth effi- ciencies. In these experiments, bacterial respiration averaged $4.75 \pm 3.50 \mu \mathrm{M} \mathrm{O}_{2} \mathrm{~d}^{-1}$ during winter. This mean value is within a factor of 2 from the mean plankton respiration suggesting that bacteria were responsible for a large fraction of the oxygen demand. Griffith et al. (1990) found that the contribution of free-living bacteria to plankton community respiration varied from 42 to $81 \%$ in coastal waters off the Georgia coast. Although bacteria generally account for most of the respiration in coastal waters (Williams 1984. Hopkinson et al. 1989, Griffith et al. 1990), the correlation between plankton community respiration and bacterial production was poor in the present study. The poor correlation between bacterial production and plankton community respiration suggests that other organisms may also be important consumers of oxygen in the Mississippi River plume. Spatial variations in bacterial growth efficiencies could also contribute to the poor correlation between bacterial production and community respiration (Hopkinson et al. 1989, Griffith et al. 1990).

\section{Bacterial growth efficiency, carbon metabolism and oxygen utilization in the Mississippi River plume}

The potential role of bacteria in the cycling of $\mathrm{C}$ can be estimated from rates of bacterial production if the bacterial growth efficiency is known. Growth efficiencies in planktonic marine systems based on comparisons between bacterial production with respiration $\left(\mathrm{CO}_{2}\right.$ production, $\mathrm{O}_{2}$ consumption) or substrate utilization range from 2 to $40 \%$ (Bjornsen 1986, Griffith et al. 1990, Bjørnsen \& Kuparinen 1991). We estimated mean bacterial growth efficiencies in Mississippi River plume waters from rates of oxygen utilization and of bacterial $C$ production. An overall mean growth efficiency of $19 \pm 6 \%$ was estimated using TdR incorporation data, and an estimate of $29 \pm 11 \%$ was determined using Leu incorporation data. The growth efficiency estimates based on Leu incorporation were generally higher than those based on TdR incorporation.

Mean integrated bacterial production in the Mississippi River plume based on TdR incorporation was $443 \mathrm{mg} \mathrm{C} \mathrm{m}^{-2} \mathrm{~d}^{-1}$ in summer and $226 \mathrm{mg} \mathrm{C} \mathrm{m}^{-2} \mathrm{~d}^{-1}$ in winter. Assuming a bacterial growth efficiency of $19 \%$ based on TdR incorporation, the amount of $C$ necessary to sustain these rates of bacterial production was $2332 \mathrm{mg} \mathrm{C} \mathrm{m}^{-2} \mathrm{~d}^{-1}$ in summer and $1189 \mathrm{mg} \mathrm{C} \mathrm{m}^{-2} \mathrm{~d}^{-1}$ in winter. Estimates of phytoplankton production in plume waters from summer of 1990 and winter 1991 were 4000 to $10000 \mathrm{mg} \mathrm{C} \mathrm{m}^{-2} \mathrm{~d}^{-1}$ and 100 to $500 \mathrm{mg} \mathrm{C}$ $\mathrm{m}^{-2} \mathrm{~d}^{-1}$, respectively (Redalje et al. 1992). Using these values, bacterial production in summer could be sustained by 23 to $58 \%$ of phytoplankton production. 
In winter, the amount of $\mathrm{C}$ needed to sustain bacterial production was 2 to 12 -fold higher than available from primary production. The same calculations using the average Leu-derived growth efficiency yielded a similar result. Bacterial production could be sustained by 10 to $40 \%$ of phytoplankton production in summer, but the $C$ requirements for bacterial growth exceeded phytoplankton production by 2 to 10 -fold in winter. During winter, materials derived from the river may support the relatively high rates of bacterial production in the plume. Dominance of a single source of substrates in winter may explain the reduced variation in bacterial growth efficiencies in winter compared to summer.

A recurrent feature of the Mississippi River plume ecosystem during summer is the presence of low oxygen concentrations $\left(<3 \mathrm{ml} \mathrm{l}^{-1}\right)$ in bottom waters west of the main river delta (Turner \& Allen 1982a, Rabalais et al. 1991). These hypoxic conditions probably result from the heterotrophic utilization of organic matter in the water column and the benthos in addition to reduced vertical mixing due to stratification (Turner \& Allen 1982a, b). Turner \& Allen (1982b) determined that plankton community respiration in the Mississippi River plume was sufficient to significantly change the oxygen concentrations in bottom waters and proposed that heterotrophic processes in the water column were the dominant factors determining the onset of hypoxic conditions in summer. The relative importance of water column respiration over benthic respiration in determining hypoxic conditions has also been proposed for areas in the Northern Adriatic (Herndl et al. 1989).

The oxygen demand by bacteria can be estimated from rates of bacterial $C$ production. During the summer cruise 4 stations were surveyed where oxygen concentrations in bottom waters were $<1 \mathrm{ml} \mathrm{l}^{-1}$. At these stations, we estimated the potential impact of planktonic bacteria in the establishment of hypoxic conditions by calculating the time required for bacteria in waters below the pycnocline to reduce the oxygen concentration from a saturated value (based on in situ temperature and salinity) to the measured in situ oxygen concentration. We assumed: (1) that the pycnocline prevented any gas exchange with overlying waters and horizontal mixing was negligible, (2) a bacterial respiratory quotient of 1 , and (3) a bacterial growth efficiency of $19 \%$. Bacterial oxygen demand would have reduced the concentration of oxygen from saturation (mean $=4.51 \pm 0.13 \mathrm{ml}$ $\mathrm{l}^{-1}$ ) to in situ levels (mean $=0.63 \pm 0.39 \mathrm{ml} \mathrm{l}^{-1}$ ) in 26 to $56 \mathrm{~d}$. Thus, estimated rates of oxygen consumption by heterotrophic bacterioplankton in subsurface waters were sufficient to establish hypoxic conditions during the summer.
Acknowledgements. This research was supported by the Coastal Ocean Program Office of the NOAA through grant NA 90AA-D-SG689 to the Texas Sea Grant Program. We are grateful to Terry Whitledge for generously allowing us to use his automated titrating system and sharing data on the concentrations of nutrients in the Mississippi River Steve Lohrenz, Don Redalje and Gary Hitchcock provided chlorophyll a data. Neil Brown Mk II CTD data, salinities determined with a Guildline salinometer and dissolved oxygen values were provided by MCRL/NOAA (Miami). We thank Jim Hendee for assistance in promptly obtaining this data. Concentrations of inorganic nutrients in the Mississippi River plume and transmissometer data from vertical CTD profiles were provided by George Berberian and Terry Nelsen, respectively. Alan Bratkovich shared his temperature and salinity data collected with a Seacat CTD. We thank the crew of the NOAA vessel 'Malcolm Baldrige' for assistance in sampling. This is contribution number 839 of the Marine Science Institute of the University of Texas at Austin

\section{LITERATURE CITED}

Albright, L. J. (1983). Influence of river-ocean plumes upon bacterioplankton production of the Strait of Georgia, British Columbia. Mar. Ecol. Prog. Ser. 12: 107-113

Ammerman, J. W. (1992). Seasonal variation in phosphate turnover in the Mississippi River plume and the inner Gulf of Mexico Shelf: rapid summer turnover. Proceedings of the NOAA Nutrient Enhanced Coastal Ocean Productivity Synthesis Workshop, Cocodrie, LA., October 1991. Texas Sea Grant Publications, TAMU-SG-92-109, Galveston, p 69-75

Azam, F., Fenchel, T., Field, J. G., Gray, J.-S., Meyer-Reil, L.-A., Thingstad, F. (1983). The ecological role of water column microbes in the sea. Mar. Ecol. Prog. Ser. 10 $157-263$

Bird, D. F., Kalff, J. (1984). Empirical relationships between bacterial abundance and chlorophyll concentrations in fresh and marine waters. Can. J Fish. Aquat. Sci. 41 1015-1023

Bjornsen, P. K. (1986). Bacterioplankton growth yield in continuous seawater cultures. Mar. Ecol. Prog. Ser. 30 191-196

Bjornsen, P. K., Kuparinen, J. (1991). Determination of bacterioplankton biomass, net production and growth efficiency in the Southern Ocean. Mar. Ecol. Prog. Ser. 71 185-194

Carritt, D. E., Carpenter, J. H. (1966). Comparison and evaluation of currently employed modifications of the Winkler method for determining dissolved oxygen in sea water. A NASCO report. J. mar. Res. 24: 286-318

Chin-Leo, G., Benner, R. (1991). Dynamics of bacterioplankton abundance and production in seagrass communities of a hypersaline lagoon. Mar. Ecol. Prog. Ser. 73: 219-230

Chin-Leo, G., Kirchman, D. L. (1988). Estimating bacterial production in marine waters from the simultaneous incorporation of thymidine and leucine. Appl. environ. Microbiol. 54: $1934-1939$

Coffin, R. B., Sharp, J. H. (1987). Microbial throphodynamics in the Delaware Estuary. Mar. Ecol. Prog. Ser. 41: 253-266

Cole, J. J., Findlay, S. Pace, M. L. (1988). Bacterial production in fresh and saltwater ecosystems: a cross-system overview. Mar. Ecol. Prog. Ser. 43:1-10

Deegan, L. A., Day, J. W., Gosselink, J. G., Yáñez-Arancibia, A., Soberón Chávez, G., Sánchez-Gil, P. (1986). Relation- 
ships among physical characteristics, vegetation distribution and fisheries yield in Gulf of Mexico estuaries. In: Wolfe, D. A. (ed.) Estuarine variability. Wiley-Interscience, New York, p. 83-102

Ducklow, H. W. (1983). Production and fate of bacteria in the oceans. Bioscience 33: 494-501

Ducklow, H. W., Kirchman, D. L. (1983). Bacterial dynamics and distribution during a spring diatom bloom in the Hudson River plume, USA. J. Plankton Res. 5: 333-355

Ellenbroek, F. M., Cappenberg, T E. (1991). DNA synthesis and tritiated thymidine incorporation by heterotrophic freshwater bacteria in continuous culture. Appl. environ. Microbiol. 57: 1675-1682

Fox, L. E., Lipschults, L., Kerkof, L., Wofsy, S. C. (1987). A chemical survey of the Mississippi estuary. Estuaries 10: $1-12$

Friederich, G. E., Sherman, P., Codispoti, L. A. (1984). A high precision automated Winkler titration system based on an HP-85 computer, a simple colorimeter, and an inexpensive electromechanical buret. Bigelow Laboratory for Ocean Sciences Technical Report No. 42. Bigelow Laboratory for Ocean Science, Westbooth Bay Harbor, Maine, USA

Griffith, P. C., Douglas, D. J., Wainright, S. C. (1990). Metabolic activity of size-fractionated microbial plankton in estuarine, nearshore, and continental shelf waters of Georgia. Mar. Ecol. Prog. Ser. 59: 263-270

Hanson, R. B. (1982). Influence of the Mississippi River on the spatial distribution of microheterotrophic activity in the Gulf of Mexico. Contr. mar. Sci. 25: 181-198

Hanson, R. B., Lowery, H. K. (1983). Nucleic acid synthesis in oceanic microplankton from the Drake Passage, Antarctic: evaluation of steady-growth. Mar. Biol. 73: 79-89

Herndl, G. J., Peduzzi, P., Fanuko, N. (1989). Benthic community metabolism and microbial dynamics in the Gulf of Trieste (Northern Adriatic Sea) Mar. Ecol. Prog. Ser. 53: $169-178$

Hollibaugh, J. T. (1988). Limitations of the $\left[{ }^{3} \mathrm{H}\right]$ thymidine method for estimating bacterial productivity due to thymidine metabolism. Mar. Ecol. Prog. Ser. 43: 19-30

Hopkinson, C. S., Sherr, B., Wiebe, W. J. (1989). Size fractionated metabolism of coastal microbial plankton. Mar. Ecol. Prog. Ser. 51. 155-166

Jonas, R. B., Tuttle, J. H. (1990). Bacterioplankton and organic carbon dynamics in the lower mesohaline Chesapeake Bay. Appl environ. Microbiol. 56: 747-757

Kieber, D. J., McDaniel, J., Mopper, K. (1989). Photochemical source of biological substrates in sea water: implications for carbon cycling. Nature, Lond. 341:637-639

Kieber, R. J., Zhou, X., Mopper, K. (1990). Formation of carbonyl compounds from UV-induced photodegradation of humic substances in natural waters: fate of riverine carbon in the sea. Limnol. Oceanogr. 35: 1.503-1515

Kirchman, D. L., Hoch, M. P. (1988). Bacterial production in the Delaware Bay estuary estimated from thymidine and leucine incorporation rates. Mar. Ecol. Prog. Ser. 45: $169-178$

Kirchman, D. L, K'ness, E. Hodson, R. (1985). Leucine incorporation and its potential as a measure of protein synthesis by bacteria in natural aquatic systems. Appl. environ. Microbiol. 49: 599-607

Kirchman, D. L., Sigda, J., Kapuscinski, R., Mitchell, R. (1982). Statistical analysis of the direct count method for enumerating bacteria. Appl. environ. Microbiol. 44: 376-382

Kirchman, D. L., Soto, Y., Wambeck, F. V., Bianchi, M. (1989). Bacterial production in the Rhone River plume: effect of mixing on relationships among microbial assemblages. Mar. Ecol. Prog. Ser. 53: 267-275
Lee, S., Fuhrman, J. A. (1987). Relationships between biovolume and biomass of naturally derived marine bacterioplankton. Appl. environ. Microbiol. 53: 1298-1303

Lohrenz, S. E., Dagg, M. J., Whitledge, T. E. (1990). Enhanced primary production at the plume/oceanic interface of the Mississippi River. Cont. Shelf Res. 7: 639-664

Malcolm, R. L., Durum, W. H. (1976). Organic carbon and nitrogen concentration and annual organic carbon load of six selected rivers in the United States, U.S. Geol. Surv. Water-Supply Pap. $1817 \mathrm{~F}$

Malone, T. C., Ducklow, H. C. (1990). Microbial biomass in the coastal plume of Chesapeake Bay: phytoplanktonbacterioplankton relationships. Limnol. Oceanogr. 35 : 296-312

McDonough, R. J., Sanders, R. M., Porter, K. G., Kirchman, D. L. (1986). Depth distribution of bacterial production in a stratified lake with an anoxic hypolimnion. Appl. environ. Microbiol. 52: 992-1000

Milliman, J. D., Meade, R. (1983). World-wide delivery of river sediment to the ocean. J. Geol. 91: 1-21

Moriarty, D. J. W. (1988). Accurate conversion factors for calculating bacterial rates from thymidine incorporation into DNA: elusive or illusive? Arch. Hydrobiol. Beih. Ergeb. Limnol. 31: 211-217

Porter, K. G., Feig, Y. S. (1980). The use of DAPI for identifying and counting aquatic microflora. Limnol. Oceanogr. 25: $943-948$

Rabalais, N. N., Turner, R. E., Wiseman, W. J. Jr, Boesch, D. F (1991). A brief summary of hypoxia on the northern Gulf of Mexico continental shelf: 1985-1988. In: Tyson, R. V., Pearson, T. H. (eds.) Modern and ancient continental shelf anoxia. Geol. Soc. Spec. Publ. No. 58, London

Redalje, D. G, Lohrenz, S. E., Fahnenstiel, G. L. (1992). The relationship between primary production and the export of POM from the photic zone in the Mississippi River plume and inner Gulf of Mexico Shelf regions. Proceedings of the NOAA Nutrient Enhanced Coastal Ocean Productivity Synthesis Workshop, Cocodrie, LA., October 1991. Texas Sea Grant Publications, TAMU-SG92-109, Galveston, p. 105-110

Riemann, B., Søndergaard, M. (1984). Measurements of diel rates of bacterial secondary production in aquatic environments. Appl. environ. Microb. 47: 632-638

Robarts, R. D., Wicks, R. J., Sephton, L. M. (1986). Spatial and temporal variations in bacterial macromolecule labeling with (methyl- ${ }^{3} \mathrm{H}$ )thymidine in a hypertrophic lake. Appl. environ. Microbiol. 52: 1368-1373

Robarts, R. D., Wicks, R. J. (1989). Methyl- ${ }^{3} \mathrm{H}$ thymidine macromolecular incorporation and lipid labeling: their significance to DNA labeling during measurements of aquatic bacterial growth. Limnol. Oceanogr. 34: 213-222

Simon, M, Azam, F. (1989). Protein content and protein synthesis rates of planktonic marine bacteria. Mar. Ecol Prog. Ser. 51: 201-213

Sklar, F. H., Turner, R. E. (1981). Characteristics of phytoplankton production off Barataria Bay in an area influenced by the Mississippi River. Contr. mar. Sci. 24: 93-106

Smits, J. D., Rjemann, B. (1988). Calculation of cell production from ${ }^{3} \mathrm{H}$ thymidine incorporation with freshwater bacteria. Appl. environ. Microbiol. 54: 2213-2219

Toolan, T., Wehr, J. D., Findlay, S. (1991). Inorganic phosphorus stimulation of bacterioplankton production in a meso-eutrophic lake. Appl. environ. Microb. 57: $2074-2078$

Turner, R. E., Allen, R. L. (1982a). Bottom water oxygen concentration in the Mississippi River Delta Bight. Contr. mar. Sci. 25: 161-172 
Turner, R. E., Allen, R. L. (1982b). Plankton respiration rates in the bottom waters of the Mississippi River Delta Bight. Contr. mar. Sci. 25: 173-179

Turner, R. E., Rabalais, N. N. (1991). Changes in Mississippi River quality this century. Bioscience 3: 140-147

White, P. A., Kalff, J., Rasmussen, J. B., Gasol, J. M. (1991). The effect of temperature and algal biomass on bacterial production and specific growth rate in freshwater and marine habitats. Microb. Ecol. 21: 99-118

This article was presented by S. Y. Newell, Sapelo Island, Georgia, USA
Williams, P. J. leB. (1984). A review of measurements of respiration rates of marine plankton populations. In: Hobbie, J. E., Williams, P. J. Leb. (eds.) heterotrophic activity in the sea, Plenum Press, New York, p. 357-389

Wright, R. T. (1984). Dynamics of pools of dissolved organic carbon. In: Hobbie, J. E, Williams, P. J Leb. (eds.) Heterotrophic activity in the sea Plenum Press, New York, p. 121-154

Manuscript first received: August 26, 1991 Revised version accepted: August 17, 1992 